\title{
Fracture Permeability: Outcrop Analogues from Active Plate Boundaries and Intraplate Contexts of Iceland
}

\author{
Maryam Khodayar ${ }^{1}$ (D), Sveinbjörn Björnsson ${ }^{2}$ \\ ${ }^{1}$ Consultant and Researcher in Geosciences, Reykjavík, Iceland \\ ${ }^{2}$ National Energy Authority of Iceland, Reykjavík, Iceland \\ Email: Profnet10@gmail.com,svb@os.is
}

How to cite this paper: Khodayar, M. and Björnsson, S. (2021) Fracture Permeability: Outcrop Analogues from Active Plate Boundaries and Intraplate Contexts of Iceland. Open Journal of Geology, 11, 621-657. https://doi.org/10.4236/ojg.2021.1112031

Received: September 28, 2021

Accepted: December 6, 2021

Published: December 9, 2021

Copyright $\odot 2021$ by author(s) and Scientific Research Publishing Inc. This work is licensed under the Creative Commons Attribution-NonCommercial International License (CC BY-NC 4.0). http://creativecommons.org/licenses/by-nc/4.0/ (c) (i) (5) Open Access

\begin{abstract}
We bring new insights into fracture permeability with 7 analogues from the intraplate outcrops of West Iceland (WI), the active South Iceland transform zone (SISZ), the intersection of rift and SISZ near Hengill (Reykjafjall-RF), and the Reykjanes oblique rift (RP). WI formed at Tertiary plate boundaries, shifted away, is now cut by the Quaternary intraplate Snæfellsnes volcanic zone (SVZ), and undergoes occasional earthquakes. By contrast, fractures are being formed and reactivated under intense plate boundary earthquakes in the younger SISZ, RF and RP. Our mapping of stratigraphy, basement fractures, surface ruptures of earthquakes, and leakages of cold and hot water in all areas shows that: 1) In active SISZ, RF and RP, permeable fractures are identical to N-S to NNW dextral, ENE to E-W sinistral, and WNW to NNW sinistral source faults of earthquakes, acting as Riedel shears that accommodate the sinistral motion of the transform zone. The NNE/NE rift-parallel extensional fractures are the least frequent permeable set. Notably, the NW and WNW sets also show dextral motions in RP where they could be splay of each other but belong to a separate developed fracture system, and in the SISZ where the NW set is a splay of a N-S source fault of earthquake. However, permeable fractures in the intraplate WI are only oblique-slip sets striking N-S to NNW dextral, ENE sinistral, and WNW dextral parallel to the SVZ. 2) In each area, the permeable sets fit the fault plane solutions of intraplate or plate boundary earthquakes, as well as the latest stress fields that allow fracture opening for fluid flow. 3) Fractures are more open in the younger SISZ, $\mathrm{RF}$, and RP, with leakages along the fractures and their splays rather than by their tips or in the stepovers. In the older WI where the crust and fractures are filled with secondary minerals, leakages are as much along fractures as where numerous fracture intersections facilitate fluid flow. 4) In case of in-
\end{abstract}


tersecting fractures, the strike and dip direction of the structures determine which set acts as a carrier or a barrier to the flow. 5) Although Iceland is more known for rifting, these analogues demonstrate that fracture permeability, block compartmentalisation, and fluid flow are controlled by the oblique-slip structures developed under transform mechanism.

\section{Keywords}

Fracture Permeability, Fluid Flow, Fractured Reservoirs, Rift Zone, Transform Zone, Tectonic of Iceland

\section{Introduction}

Permeable fractures act as natural channels for fluid migration in any rock type and tectonic context. Such permeability is particularly critical in geothermal and hydrocarbon fractured reservoirs when drilling has to target the best flow paths, re-injection triggers earthquakes, e.g. [1], or natural fluid flow generates earthquakes, e.g. [2]. The criteria to identify structural permeability are the fracture strikes, motions, geometries, fault zone architectures [3] [4] [5] [6], stress field [7] [8] [9] [10] and fault-slip data [11] [12]. Imaging and software are means for sub-surface fracture identification, conceptual modelling and simulation, especially in geothermal reservoirs with risk of induced seismicity [13] [14] [15] [16]. However, outcrop analogues are open windows to the natural state of fractures, and have been subject of intensive studies.

Diverging plate boundaries are spreading centres where rifting occurs by the way of faulting, volcanism and earthquakes, and geothermal and hydrocarbon resources accumulate in normal fault-controlled basins, e.g. [3] [17] [18]. The extensional fractures strike parallel to rift segments and perpendicular to spreading, and normal fault slips favour the flow paths along the structures. Transform segments [19], transfer zones [20] [21], and oblique rifts [22] [23] [24] are integral parts of rift systems. They are oblique to the direction of spreading and develop internal conjugate shear fractures alongside extensional structures. With time, additional complexities arise from bookshelf tectonic and rotation [25] [26] within transform segments [27] [28] [29] or between overlapping rifts, e.g. [30] [31], and from stress permutation causing fracture reactivation with different motions [32] [33] [34]. Block rotation between plate boundary segments [35] [36] [37], and increase in rift obliquity [38] [39] also lead to gradual curvature and sinuosity of fractures [17] [40] [41].

Regardless of scale [42], strike-slip faults are either parallel continuous segments with straight geometry [43] [44] [45], or en échelon arrays that are surface expression of deeper shear faults [46] [47] [48] [49]. In both these types, the stepovers linking the segments are zones of slip transfer where local stress reorientation leads to formation of complex structural patterns with extensional, shear, or mixed interlinked fractures [50] [51] [52]. Several such sets could in- 
tersect in the stepover zones as a result of polyphase tectonics [2] [53]. Stepovers could evolve with time into pull-apart basins under strike-slip regime [17], or to rhomb-graben basins under transtension or oblique extension [35] [54] [55].

Due to intense fracturing and fracture connectivity, both the relay zones of normal faults [21] and the stepovers between strike-slip segments [46] [56] form permeable structural zones for accumulation of hydrocarbon and hydrothermal resources [52]-[59]. Not the least, the stopovers of strike-slip zones are considered to be loci of seismic rupture nucleation [52] [60] [61], with strong interactions between earthquakes, fracture opening and fluid flow, e.g. [2].

In addition to stepovers, pull-aparts, and relay zones, permeability is also enhanced at the horsetail splays of strike-slip faults, as well as fault intersections [6] [53] [62] particularly in dense fracture network where a high number of intersecting fractures creates multiple opening for fluid flow. Other criteria affecting the flow are the fault zone architectures and the thickness of fault gouge/breccia [3] [59] [63], which develop as segments coalesce, faults become longer and slip increases [64]. Furthermore, the percentages of fault core and damage zone, the grain sizes, and the fluid chemistry determine whether a fault zone is a barrier or conduit to the flow, e.g. [65] [66]. In transfer areas between faults, the condition would also depend on the directional permeability compared to fault strikes, fault intersections and slip vector [2].

The above insights come largely from continental crust, reflect tectonic processes that evolved over long geological time period, and mostly away from active plate boundaries. The 7 outcrop analogues in this paper discuss fracture permeability in an oceanic crust, with six examples from active transform zone, intersection of rift and transform segments, and oblique rift, and one from an intraplate context that formed at Tertiary plate boundaries and shifted away. We aim at demonstrating the features of host fractures to the observed leakages of cold and hot water, and not at determining the upflow and outflow zones of geothermal fields. For this, we:

- Present the mapped stratigraphy, bedrock fractures, surface ruptures of earthquakes, and leakages.

- Interpret the structural control of permeable fractures along with quick analysis of compatible stress fields, as well as brief correlation with earthquake and stress data from literature.

- Summarise the findings and provide concluding remarks.

This contribution brings new insights into fracture permeability from Iceland where few examples have been reported in the literature up to now. Our results show the complexity and the dominant mechanism controlling fracture permeability in extensional plate boundaries where permeability is generally attributed to rift-parallel extensional fractures.

\section{Geological Settings}

\subsection{Iceland}

Iceland displays a complex tectonic spanning Upper Tertiary to present. Above a 
hotspot [67] [68], the American and Eurasian Plates separate at a rate of $2 \mathrm{~cm} / \mathrm{yr}$ in the direction of $\mathrm{N} 105^{\circ} \mathrm{E}$ [69] along several active plate boundaries, which are loci of intense earthquakes, magmatism, and geothermal activity (Figure 1(a)). The active rifts are the Kolbeinsey Ridge, the Northern and the Eastern Rift Zones (NRZ and ERZ), and the Western Rift Zone (WRZ). The transform segments are the Tjörnes Fracture Zone (TFZ) and the South Iceland Seismic Zones (SISZ), and the microplates are in Grímsey-Tjörnes-Dalvík and Hreppar [70]. Oblique rifting occurs in Reykjanes Peninsula (RP) [39] [71], Reykjanes Ridge [38] [72] [73], and around Grímsey [74]. The oceanic crust consists of basaltic and acidic series, with intercalated hyaloclastites and sediments. The oldest series date from 16 - 15 Ma, emitted from the now extinct Snæfellsnes Rift Zone [75] [76] [77], and possibly $24 \mathrm{Ma}$, emitted from the Northwest Rift Zone [78]. At least one Tertiary transform segment is considered in central Iceland [76]-[81]. In West Iceland, the Tertiary structures are cut by the Quaternary intraplate Snæfellsnes Volcanic Zone (SVZ) [79]. Icelandic rift segments and the microplates that formed within rifts are characterised by normal faults, eruptive fissures, and central volcanoes arranged in swarms that strike N-S in NRZ, but NNE/NE in WRZ, ERZ, West Iceland and Hreppar Microplate. The transform segments primarily identified by earthquakes [82] [83] [84] are with dextral motion along the TFZ, and sinistral motion along the SISZ, both having internal Riedel shears, e.g. [29] [85]. As a result of a continuous tectonic since Upper Tertiary, the crust is structured with flexures, erosional unconformities, and an intense fracture network [70] [86] [87] [88] that reflect severe stress field fluctuations over time [34] [89] [90] [91].

\subsection{The Study Areas}

The 7 analogues are in the intraplate outcrops of West Iceland, but mostly within the active SISZ, at its intersection with the WRZ, and within the RP oblique rift (Figure 1(b)).

- In South Iceland, the 3.4 - 0.7 Ma bedrock consists of basalts, hyaloclastites, local acidic rocks and intercalated sediments in Hreppar [92]. Based on mineral assemblages [93], the bedrock in Hreppar is eroded down to $0.7 \mathrm{~km}$. The interglacial lavas $(<0.7 \mathrm{Ma})$ cover mostly the series of Hreppar while the late glacial formation and the 8600 yrs bjórsá lava [94] are more widespread in the SISZ. Reykjanes is covered by the post glacial lavas $14,500 \mathrm{yrs}-13^{\text {th }}$ Century, with isolated hyaloclastite ridges $<0.115 \mathrm{Ma}$ [95], which are found down to $400 \mathrm{~m}$ in wells above older bedrock, e.g. [96]. The transform zone of SISZ is considered to have an overall $\mathrm{E}-\mathrm{W}$ strike, with a width of $\sim 25 \mathrm{~km}$, a length of $80 \mathrm{~km}$ or more [97], a sinistral motion and a constant slip-rate of 19 $\pm 1 \mathrm{~mm} / \mathrm{yr}$ [29] [98]. A recent study, however, demonstrates that the SISZ likely strikes ENE and could be bounded by ENE oblique-slip sinistral faults [88]. The literature agrees that from WRZ to the RP, the transform zone strikes ENE, is up to $20 \mathrm{~km}$ wide, and is highly oblique [71] [99]. Oblique 


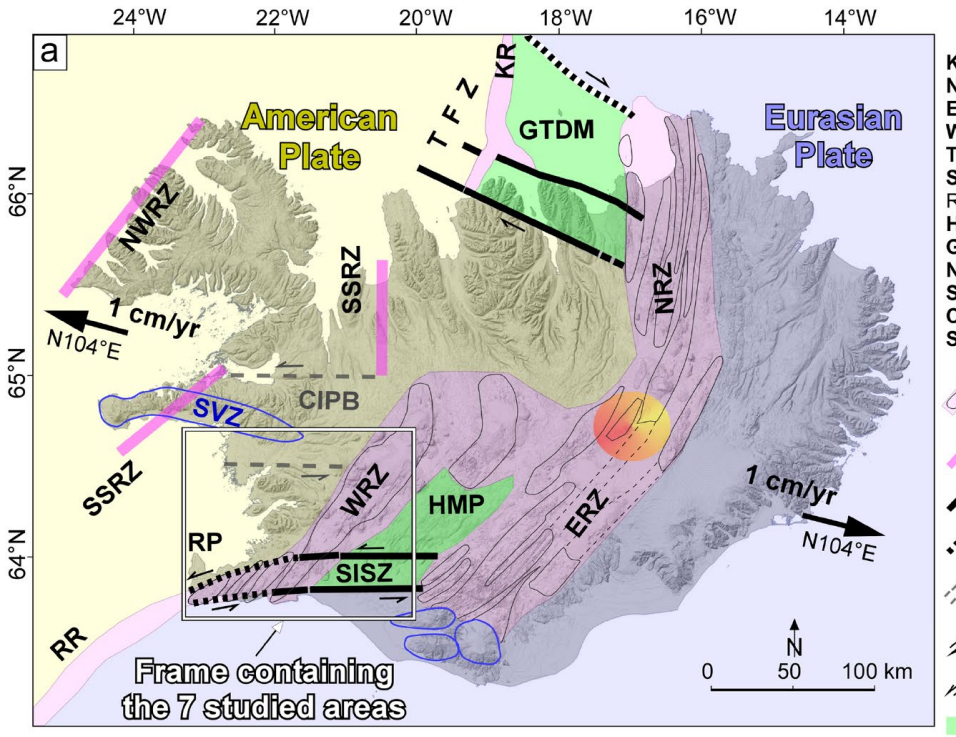

\section{Legend common to all figures}

KR: Kolbeinsey Ridge

NRZ: Northern Rift Zone

ERZ: Eastern Rift Zone

WRZ: Western Rift Zone (Reykjanes-Langjökull Rift Zone)

TFZ: Tjörnes Fracture Zone

SISZ: South Iceland Seismic Zone

RP: Reykjanes Peninsula; RR: Reykjanes Ridge

HMP: Hreppar Microplate

GTDM: Grímsey-Tjörnes-Dalvík Microplate

NWRZ: Northwest Rift Zone

SSRZ: Snæfellsnes-Skagi Rift Zone

CIPB: Central Iceland plate boundary

SVZ: Snæfellsnes Volcanic Zone (Quaternary intraplate)

$\begin{array}{lll}\begin{array}{l}\text { Active rift and rift } \\ \text { fissure swarm }\end{array} & \begin{array}{l}\text { Centre of hotspot } \\ \text { Extinct rift segment }\end{array} \\ \begin{array}{l}\text { Active transform zone } \\ \text { Quaternary intraplate } \\ \text { volcanism }\end{array} \\ \begin{array}{l}\text { Direction of spreading } \\ \text { Oblique rift }\end{array} \\ \begin{array}{l}1974 \text { intraplate } \\ \text { earthquakes } \\ \text { transform zone }\end{array} \\ \begin{array}{l}\text { Dextral motion } \\ \text { Plathquakes at active }\end{array} \\ \text { Ministral motion } & \begin{array}{l}\text { Geothermal gradient } \\ \left({ }^{\circ} \mathrm{C} \text { per km) }\right.\end{array} \\ \text { Microplate } & 1 \square \text { Study areas }\end{array}$

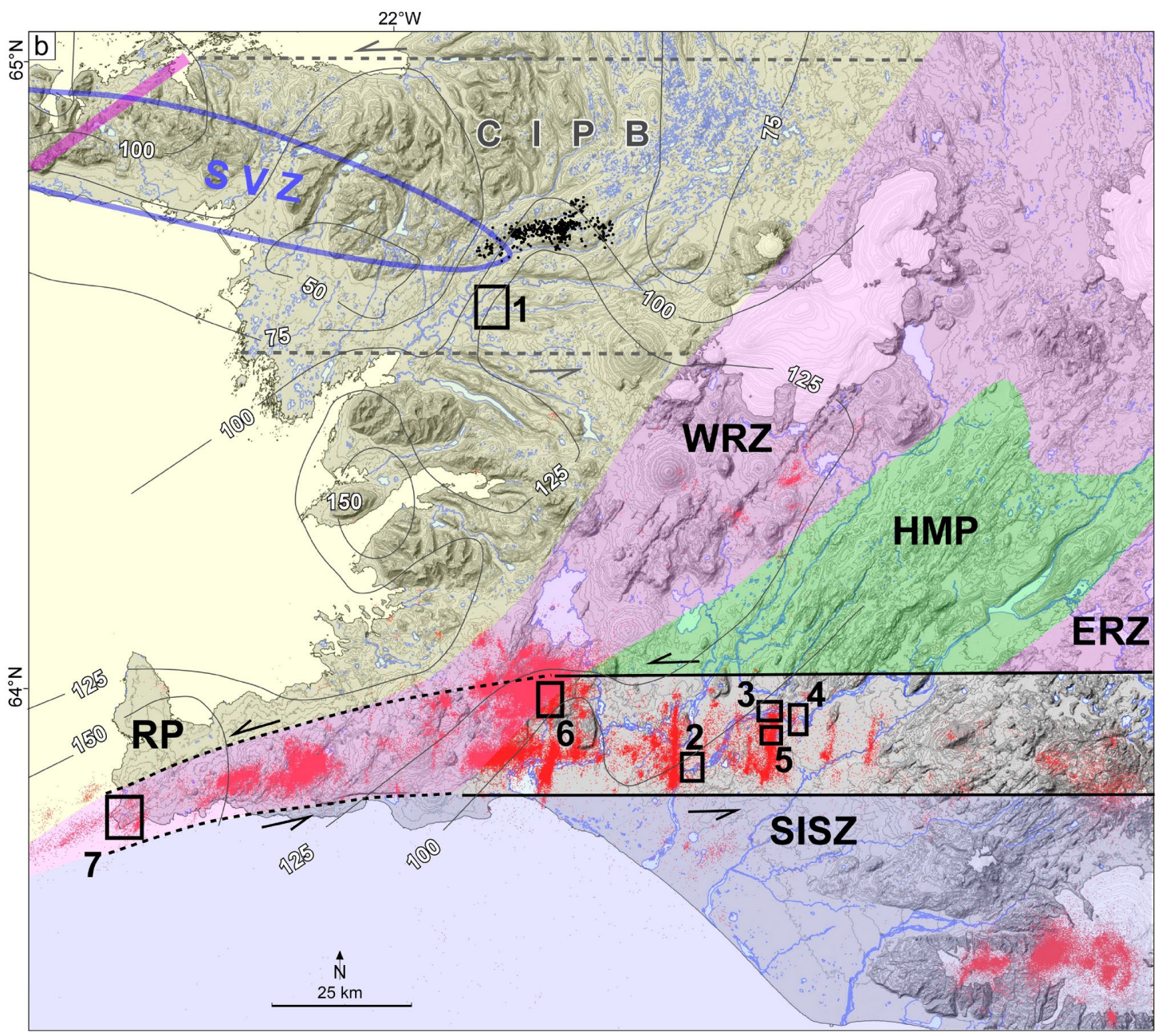

Figure 1. (a) Active and extinct plate boundaries, and microplates in Iceland (modified from [70]). Fissure swarms and intraplate volcanism from [119], earthquakes from Icelandic Meteorological Institute (IMO), hotspot from [68], and the spreading rate from [120]. (b) Locations of the 7 studied areas in the intraplate West Iceland, in the active South Iceland transform zone, at the intersection of rift and transform segments, and in the Reykjanes oblique rift. The 1974 intraplate earthquakes in Area 1 are from [109], and the geothermal gradient from [110]. 
rifting and magmatic phases seem alternating on the RP, and the plate boundary undergoes presently transtension, with both sinistral motion and extension [100]. Earthquakes are frequent in the SISZ and on the RP, reaching $M_{L}$ 7. The last major events in the SISZ are the 2000 and 2008 earthquakes (SIL network), and those on the RP are the earthquake swarms of 1972 [101], continued to 1973 [102], as well as those in 2013-2015 [103] [104]. The surface ruptures of earthquakes in both the SISZ and on the RP are primarily the conjugate N-S dextral and ENE sinistral strike and oblique slip faults [29], and secondarily the WNW, NW and E-W Riedel shears [88] [105] [106]. The surface ruptures display left- and right-stepping en échelon arrangement, indicative of dextral and sinistral motions. It is noteworthy that in Reykjanes, the WNW and NW structures are prominent both at the surface [107] and in resistivity anomalies at depth [108].

- The crust in West Iceland formed at the SRZ between $16-15$ and 5/7 Ma, then in the WRZ from 6 to $\sim 3 \mathrm{Ma}$ [75] [77]. The series consist of basalt and intercalated sediments, which, based on zeolite assemblages [93] are eroded down to $1.5 \mathrm{~km}$ depth. Erosional unconformities separate the stratigraphic units of the two Tertiary rifts (Figure 2(a)). Rift-parallel structures strike NNE to NE, but the same Riedel shear pattern as in the SISZ and RP is also present. Dyke injection into Tertiary N-S dextral oblique fault segments similar to those in the SISZ indicates that a sinistral Tertiary transform zone may have connected the two Tertiary rift segments [81] (Figure 1(a)). The Quaternary intraplate volcanism (SVZ) consists of WNW segments with dextral motion [76] [86], and the 1974 intraplate earthquakes at its eastern tip show primarily extension along all fracture sets [109]. The SVZ appears to fall within the Tertiary transform zone, but superimposed on all sets of underlying Tertiary faults and dykes [81].

- The highest geothermal gradients are considered to be in rift segments [110] (Figure 1(b)) with reservoirs reaching up to $380^{\circ} \mathrm{C}$ at $2 \mathrm{~km}$ depth [111]. In most cases, however, such reservoirs are located at the intersection of rift and transform zones. Low and medium temperature gradients are generally on rift shoulders and within the SISZ where temperatures reach $175^{\circ} \mathrm{C}$ at $2 \mathrm{~km}$ depth [111]. Structural permeability that facilitates the leakages of cold or hot water is traditionally attributed to rift-parallel extensional fractures in Iceland. However, structural analyses in many areas of Iceland show that rift-parallel fractures represent up to $1 / 3$ of any fracture population [70] [88] [107].

\section{Method and Data}

The 7 examples of fracture permeability were observed during several intensive field campaigns to map the stratigraphy and tectonic structures for geothermal exploration and seismic risk assessment. The analogues represent leakages of cold and warm water in the intraplate outcrops of West Iceland (Figure 2), 
within the SISZ (Figures 3-6), at its intersection with the WRZ (Figure 7 and Figure 8), and in the Reykjanes oblique rift (Figure 9). In each area, we provide in detail the stratigraphy along with the mapped regional basement fractures, surface ruptures, leakages, and the overview of their tectonic control. We then compile the structural configurations of all permeable fractures, and correlate them briefly with earthquake data and the directions of Shmax from literature (Figure 10). All observed fracture patterns, along with their interpreted geometries and compatible stresses, are summed up on Figure 11. Finally, the features of the permeable fractures in each tectonic context, the most frequent geometries, and some considerations regarding the flow paths are summarised on Figure 12. Two points should be noted:

- The terms "older" and "younger" fractures are used to distinguish the relative age of structures. Older fractures are in bedrock and have sharper traces as segments coalesced over time and accumulated slips. Younger fractures are the surface ruptures of earthquakes. As they have not yet coalesced, they are en échelon arrays of sinkholes, open fractures, linear breaks and push-ups, appearing either above deeper shear fractures or along older shear fractures that have broken the surface. The magnitude of horizontal motions cannot be easily estimated due to lack of marker horizons, but in general, the dip-slip in a single earthquake is up to $1.5 \mathrm{~m}$ [105], and the strike-slip in order of $2 \mathrm{~m}$ [98]. The senses of horizontal motions were thus deduced from the left- and right-stepping arrangements of fracture segments, and when present, by striae on the planes of older fractures in outcrops.

- Our interpretation of permeable fractures takes into account that leakages are on steeply-dipping fractures, $75^{\circ}$ to $90^{\circ}$, as observed in earthquake data [112] and in outcrops, e.g. [88].

\section{Observations}

\subsection{Area 1: Borgarfjörður of West Iceland}

Area 1 is covered by the 6 to $\sim 3 \mathrm{Ma}$ basaltic lavas on the hills and by the 10,000 yrs old silt and clay in the valleys. Geothermal manifestations were mapped in three clusters in the younger sediments (Figure 2(a)), located at some $10 \mathrm{~km}$ to the southwest of the 1974 earthquakes (Figure 2(b)). From north to the southwest, the geothermal clusters and the number of mapped features within them are Hurðarbak (60); Deildartunga (56), Kársnes (36), Kleppjárnsreykir (30); and Klettur, Runnar (207), summing up to a total of 389 geothermal features.

The older fractures in the bedrock present several sets, but two peaks at NNE to NE (parallel to rift) and ENE to WNW stand out. All sets have dip- and strike-slips, but the shear motions are complex as the same set can display opposite sense of motions indicating a polyphase tectonic (Figure $2(\mathrm{c})$ ). The aftershocks of 1974 earthquakes spread in an area of $\sim 25 \mathrm{~km}$ long and $9 \mathrm{~km}$ wide, with seismic lineations oriented ENE, NNE, and then N-S and WNW (Figures 2(a)-(c)). The 389 mapped geothermal features align dominantly N-S and ENE, 

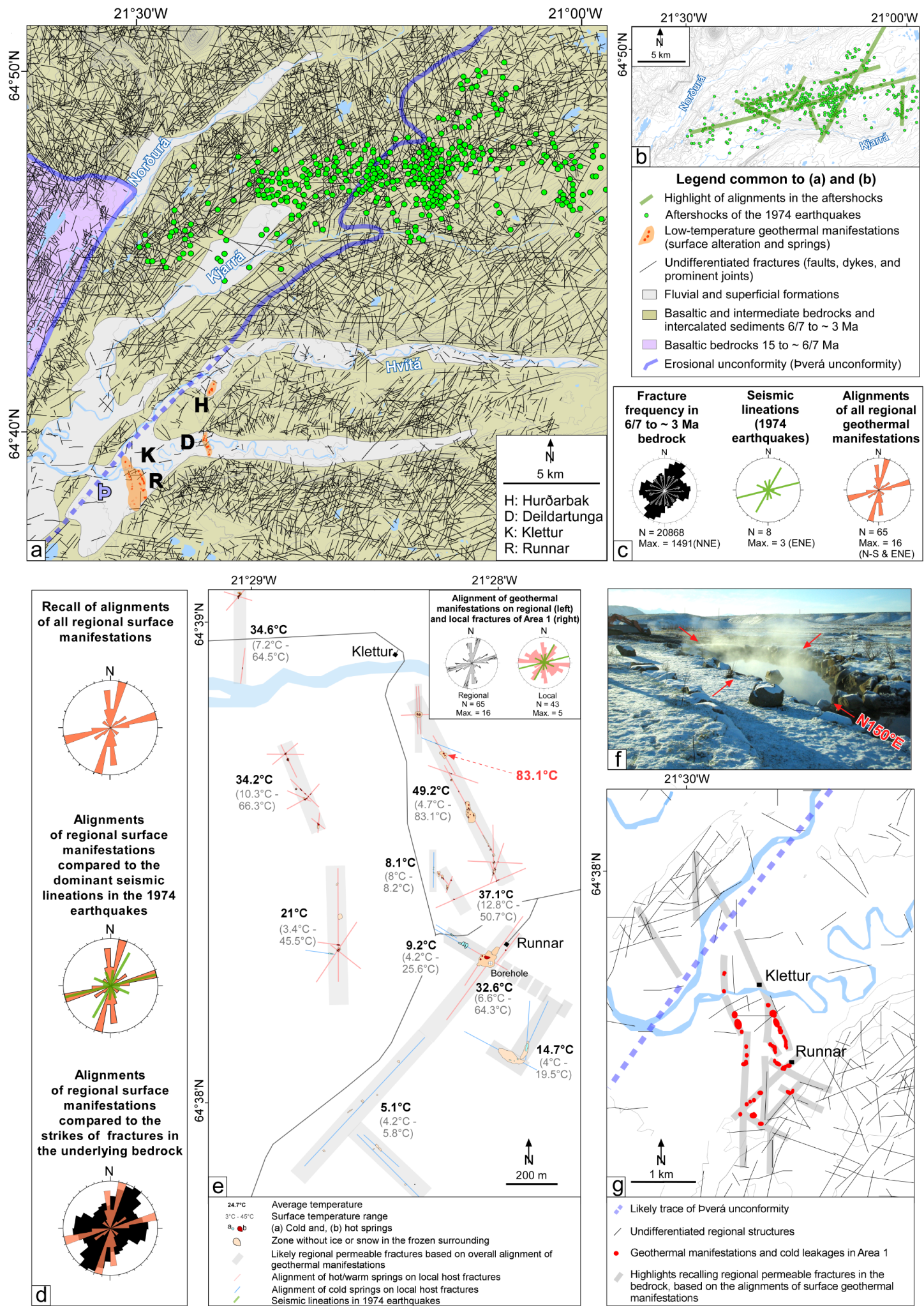

Figure 2. Area 1, Borgarfjörður in the intraplate outcrops of West Iceland. (a) The mapped geothermal manifestations in the Tertiary crust, the regional fracture network, and the location of the 1974 earthquake swarm. (b) The 1974 seismic lineations. (c) Separate, and (d) comparative rose diagrams of regional fractures, seismic lineations, and the host fractures to leakages. (e) Close-up on the mapped leakages and host fractures. (f) A NW-striking hot spring. (g) Correlation of the permeable fractures and the surrounding fracture network. 
secondarily NNW, and lastly WNW, but not NNE parallel to the rift. These regional alignments fit relatively well the seismic lineations rather than the dominant strikes of the underlying older bedrock fractures (Figure 2(d)).

The geothermal manifestations of Klettur-Runnar are selected for the analysis here as they are the longest cluster (Figure $2(\mathrm{e})$ ). The features mapped in detail are few cold springs $\left(1^{\circ} \mathrm{C}-9.9^{\circ} \mathrm{C}\right)$, a majority of warm $\left(10^{\circ} \mathrm{C}-49.9^{\circ} \mathrm{C}\right)$, a few hot springs $\left(50^{\circ} \mathrm{C}-83.1^{\circ} \mathrm{C}\right)$, and one borehole $\left(64.3^{\circ} \mathrm{C}\right)$. Warm soil with occasional steam, and a few metre-scale zones free of snow and ice during winter were also mapped indicating possible nearby geothermal source. The host fractures to the leakages are covered by superficial formation, and are deduced from the alignments of the leakages, falling in the continuation of the fracture sets of the same strikes in the immediate surrounding bedrock. These permeable fractures are not surface ruptures of 1974 earthquakes, but reactivated fractures of the bedrock reflecting the present-day tectonic activity that keeps the fractures open for fluid flow. As such, the most dominant permeable set appears to be NNW, which is also the orientation of the bigger springs (Figure 2(f)), then NE, N-S, and WNW. They are, however, not aligned ENE similar to the main seismic lineations of 1974 earthquakes. Despite the leakages align on regional fractures, the flow to the surface is equally facilitated by fracture intersections (Figure 2(d) and Figure 2(e) and Figure 2(g)).

\subsection{Area 2: Heiðartangi in the SISZ}

Area 2 is covered by Pjórsá lava and fini-glacial loose overburden, but the lava and tillite belonging to Hreppar formation (3.1 - 0.7 Ma) crop locally at Heiðartangi where the leakages of cold water were mapped (Figures 3(a)-(g)). Although Hreppar formation was formed at the rift and should be dominantly with NNE structures, the most frequent older bedrock fractures here are the ENE sinistral and N-S dextral oblique-slip faults, and several ENE and one N-S dyke segments (Figure 3(a) and Figure 3(b)). Area 2 is the site of the 1896 earthquakes, but also adjacent to the site of the 21 June 2000 earthquake that occurred to the west of Urriðafoss. The main surface ruptures of these earthquakes are the N-S dextral and ENE sinistral conjugate sets cutting the Hreppar formation and the Pjórsá lava [29] (Figure 3(a) and Figure 3(b)). Detailed mapping of the historic surface ruptures by this study, however, shows that regionally, along with the N-S and ENE structures, other sinistral Riedel shears striking WNW and ENE also ruptured the surface (Figure 3(b)). Albeit minor, all sets also display dip-slip. The mapped leakages are cold springs, filled and dried-up ponds, and rare warm springs up to $24^{\circ} \mathrm{C}$. They align clearly on the N-S dextral, then equally on the ENE and NW sinistral fractures, but less on the E-W sinistral and the NNE extensional fractures. At the tip of Heiðartangi near the shore of Pjórsá, the leakages appear through the tholeiite lava, which is cut heavily by N-S, ENE, NW and WNW joints (Figure 3(c)). Such joints are widespread between Heiðartangi and Urriðafoss (Figure 3(d) and Figure 3(e)), sometimes forming 

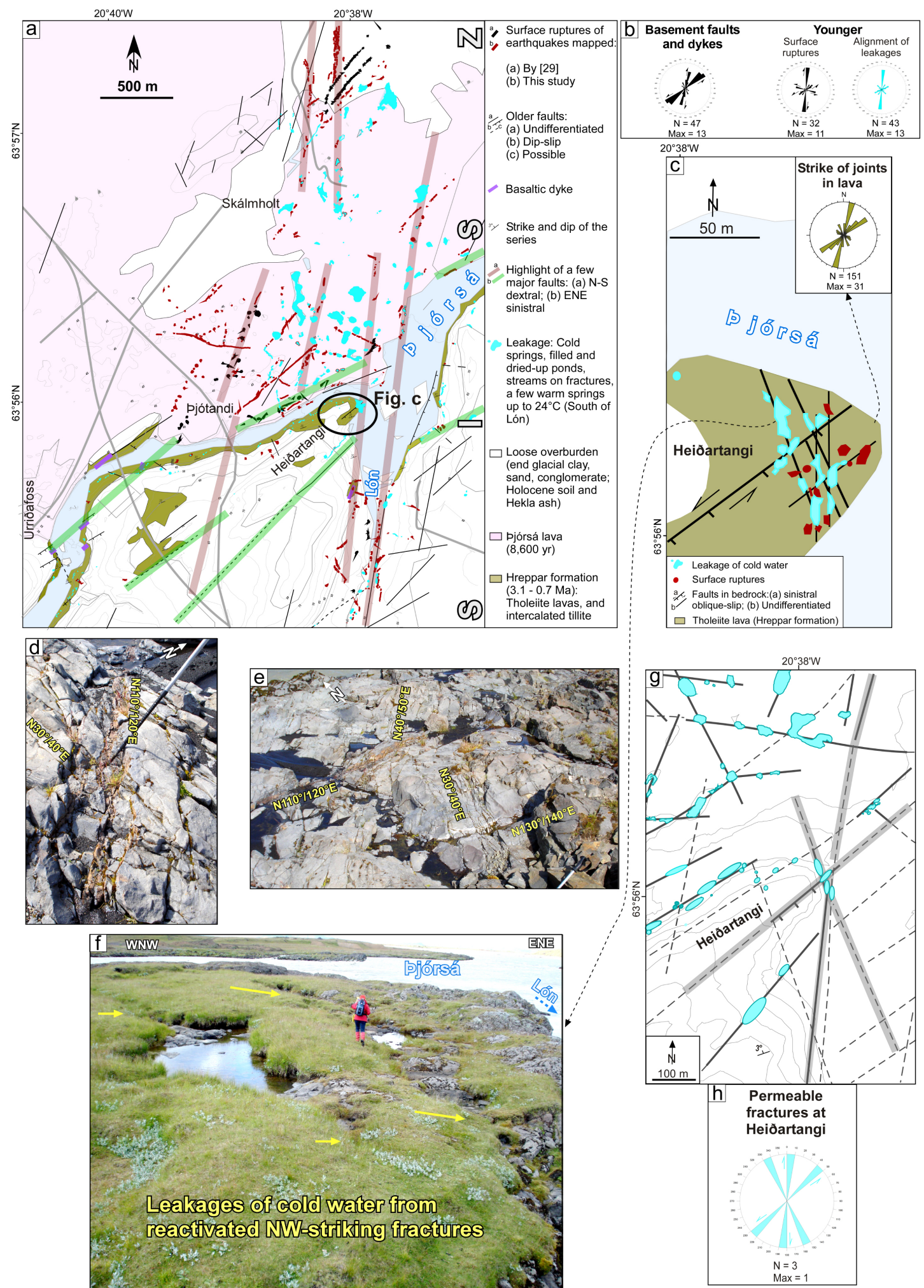

Figure 3. Area 2, Heiðartangi in the SISZ. (a) Mapped regional stratigraphy, older and younger fractures, the leakages, and location of the study area. (b) Rose diagrams of regional fractures and the alignments of the leakages. (c) Close-up on leakages along older and younger fractures, and the rose diagram of joints in the basement rock. (d) Fault breccia along a WNW dextral fault. (e) NNE joints intersecting WNW strike-slip segments. (f) Leakages along NW surface ruptures (yellow arrows). (g) and (h) Highlights of leakages, permeable fracture sets, and their rose diagram. 
narrow brecciated fault zones critical for fracture permeability. Clear examples of fracture permeability along NW and ENE sinistral, and N-S dextral oblique-slip faults are the cold leakages in Heiðartangi (Figure 3(c) and Figure 3(f)).

Although Heiðartangi is caught between two major N-S dextral and two ENE sinistral oblique-slip regional fractures, the leakages align on regional N-S and ENE structures but more so on local NW fractures (Figures 3(f)-(h)). Clearly, the permeable fractures are the bedrock structures reactivated during earthquakes, with leakages mostly along the main fracture segments rather than at the fracture intersections.

\subsection{Area 3: Akbraut in the SISZ}

Area 3 in Akbraut is at some $17 \mathrm{~km}$ farther to the northeast of Heiðartangi and displays leakages of cold water (Figures $4(\mathrm{a})$-(g)). The outcrop is within the SISZ (Figure 1(b)), very near the northern boundary of the transform zone and adjacent to the southern limit of the extinct Stóra-Laxá central volcano within the Hreppar Microplate. The central volcano is covered by the interglacial lava < $0.7 \mathrm{Ma}$, while bjórsá lava and superficial formations cover the lowland around Akbraut. The outcrop analogue is on a small hill made of the same interglacial lava as in the Stóra-Laxá central volcano (Figure 4(a) and Figure 4(c)). Although the NNE rift-parallel fractures are widespread in the interglacial lava of the central volcano, overall, the older bedrock regional fractures in Hreppar and SISZ are dominantly the N-S dextral and ENE sinistral, then the WNW/NW sinistral oblique-slip faults (Figure 4(b)). The surface ruptures of the historic and the 2000 earthquakes are located to the north, east, and south of Akbraut, and they are dominantly N-S dextral.

The leakages of cold water in Akbraut are springs, filled or dried-up elongated ponds that form clusters, as well as three abandoned shallow wells (Figure 4(c)). The leakages form distinct northerly, NNE, ENE and WNW/NW clusters, with left- or right-stepping arrangements similar to surface fractures (Figure 4 (d) and Figure 4(e)). They are indeed directly located on the traces of the underlying N-S dextral, and the NNE rift-parallel structures, then on the traces of ENE sinistral, and finally the NW and WNW oblique-slip sinistral shears fractures (Figure 4(f) and Figure 4(g)). Given these frequencies, permeability is dominantly controlled by the Riedel shears of the transform zone. Although the total length of each individual permeable fracture is unknown, the leakages seem to be in the middle sections of the fractures rather than by their tips. This does not exclude that fracture intersection also plays a role in increased permeability.

\subsection{Area 4: Laugar in the SISZ}

Area 4 in Laugar (Figure 5(a)) is to the northeast of the island of Árnes, and at some $5 \mathrm{~km}$ to the east of Akbraut. The outcrop is within the SISZ and includes both low temperature geothermal activity and a few small leakages of cold water. 

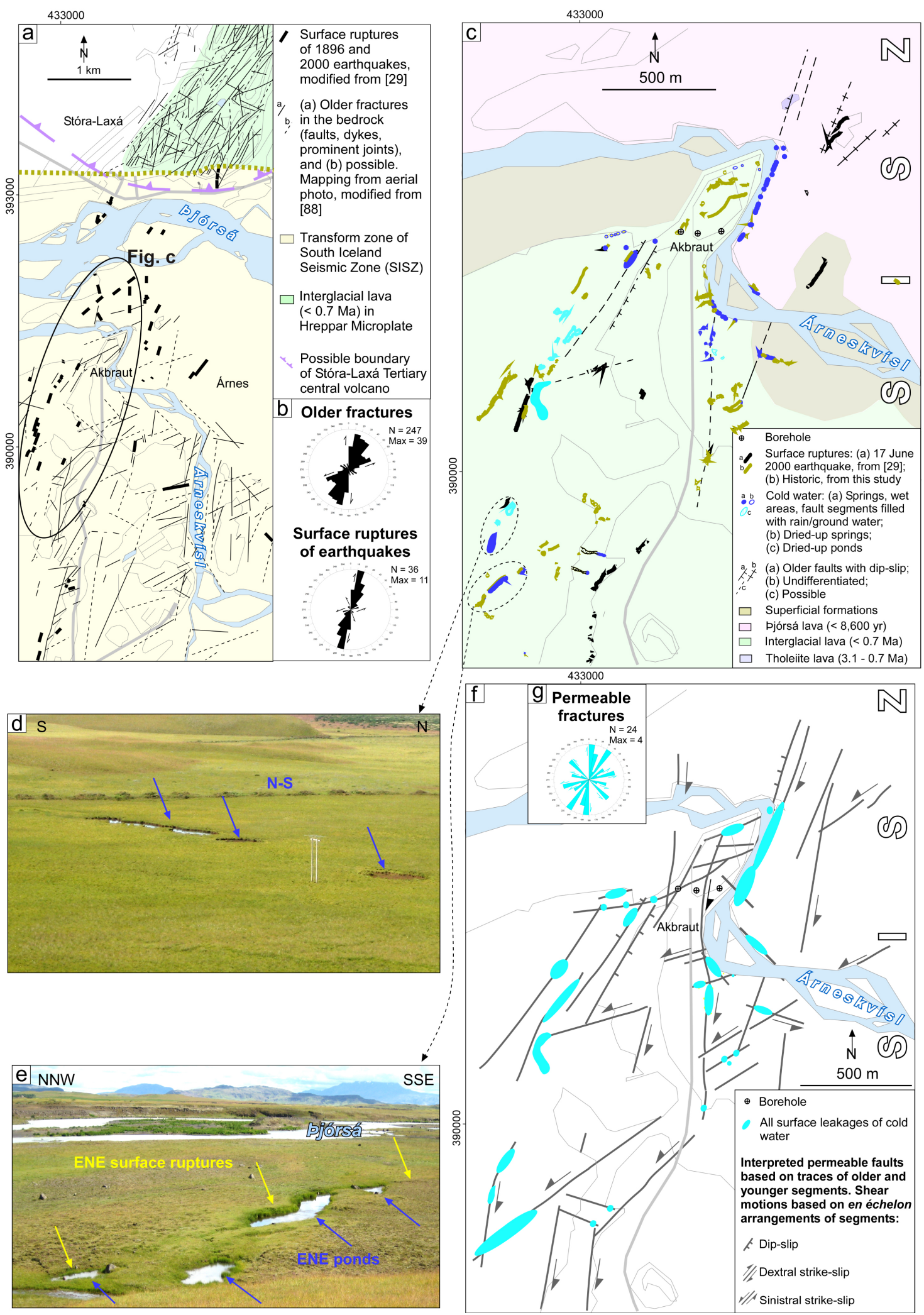

Figure 4. Area 3, Akbraut in the SISZ. (a) Mapped regional stratigraphy, older and younger fractures, and the study area. (b) Rose diagrams of regional older fractures and surface ruptures. (c) Close-up on cold-water leakages, older faults and younger surface ruptures. (d) and (e) Examples of leakages arranged in N-S left- and ENE right-stepping arrays. (f) and (g) Highlights of leakages, permeable fracture sets, and their rose diagram. 

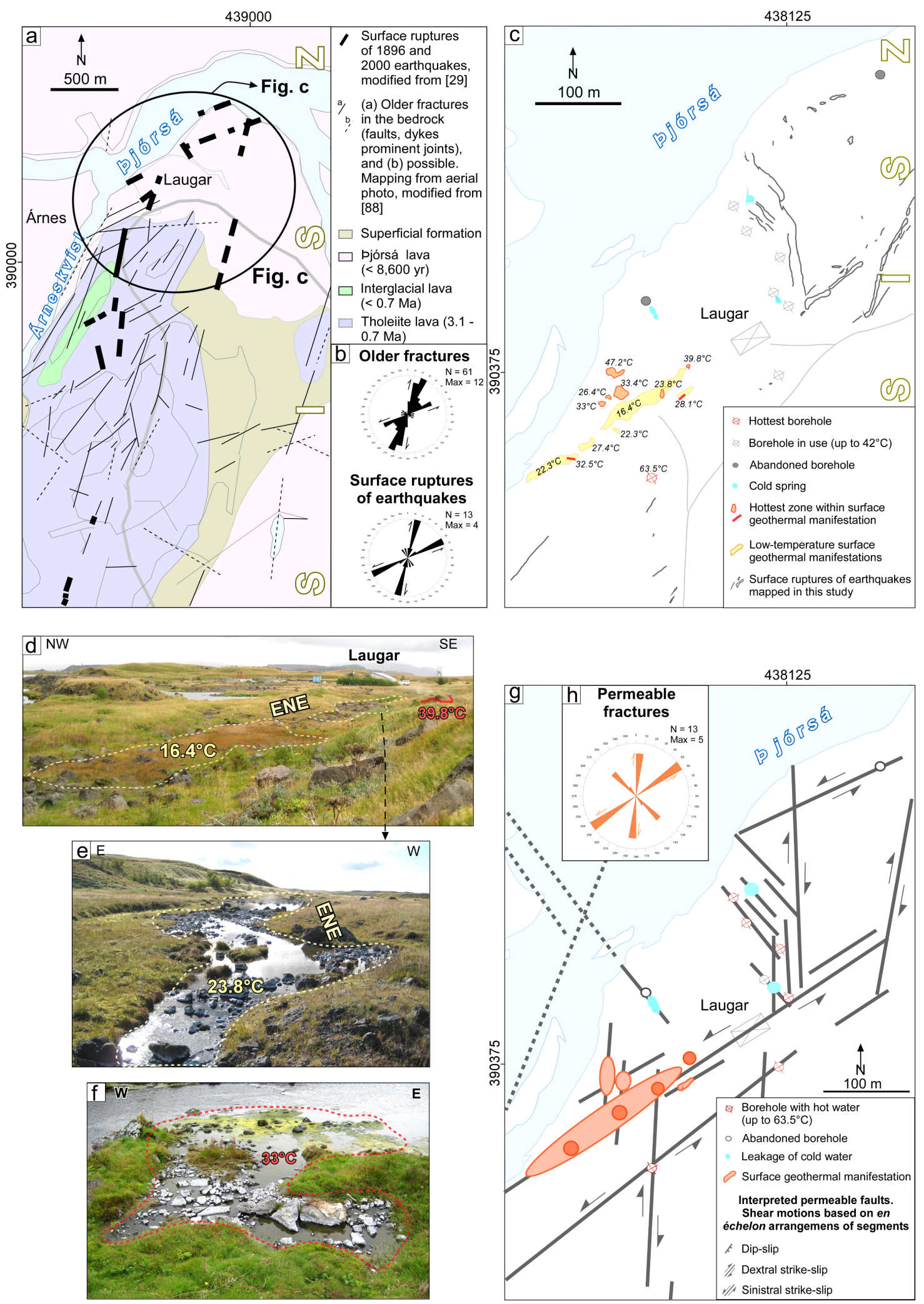

Figure 5. Area 4, Laugar in the SISZ. (a) Mapped regional stratigraphy, older and younger fractures, and the study area. (b) Rose diagrams of the older and younger fractures. (c) Close-up on mapped geothermal manifestations and fractures. (d) to (f) ENE clay zone, a steamy hot water pond, and current mineral deposition in a springs. (g) and (h) Highlights of leakages, permeable fracture sets, and their rose diagram. 
The Pjórsá lava and the superficial formations cover the lowland, but the hills immediately surrounding Laugar are made of the tholeiite lavas of Hreppar formation, and by the interglacial lavas (Figure 5(a)). Laugar is adjacent to the site of the 1630 earthquake. Additionally, the N-S and ENE oblique-slip surface ruptures of the 1896 earthquakes cut directly the bedrock, the Pjórsá lava and the superficial formation in this site. Although the NNE rift-parallel structures should be dominant in the bedrock that was formed in the rift, the older regional fractures here are dominantly the northerly dextral and the ENE sinistral oblique-slip Riedel shears, and secondarily the NNE and WNW structures (Figure $5(b))$.

The mapped features in this site are the surface ruptures, the altered geothermal zones, a few warm and cold springs, and 9 wells (Figure 5(c)). The surface ruptures are the right-stepping ENE en échelon sinistral segments, a few WNW and NW undetermined fractures mainly to the northeast, then a few left-stepping $\mathrm{N}-\mathrm{S}$ dextral arrays. Geothermal manifestations are warm swampy soil (Figure $5(d)$ ) and a steamy elongated pond (Figure $5(\mathrm{e})$ ) with $16.4^{\circ} \mathrm{C}$ to $22.3^{\circ} \mathrm{C}$ temperature that occupies a narrow ENE zone in the western part of the area, in continuation of the ENE surface ruptures. A few warm springs outside of the main ENE altered zone are $26.4^{\circ} \mathrm{C}$ to $47^{\circ} \mathrm{C}$, with evidence of current alteration mineral deposition (Figure $5(\mathrm{f})$ ). The hottest features related to the ENE altered zones are two warm springs $\left(23.8^{\circ} \mathrm{C}\right.$ and $\left.39.8^{\circ} \mathrm{C}\right)$ and two short linear features aligned $\mathrm{E}-\mathrm{W}$ and $\mathrm{ENE}\left(32.5^{\circ} \mathrm{C}\right.$ and $\left.28.1^{\circ} \mathrm{C}\right)$. The cold springs farther to the northeast are with low discharge, and they are near most of the drilled wells that reach up to $42^{\circ} \mathrm{C}$.

The structural data demonstrate that geothermal activity is mainly along the ENE sinistral surface ruptures and secondarily along the N-S dextral source fault, with the hottest producing well $\left(63^{\circ} \mathrm{C}\right)$ at the intersection of these two sets. The cold springs, on the other hand, are on the traces of NW fractures. This analogue reflects the strong control of fracture permeability by the Riedel shears of transform zone where the leakages are along the fracture traces rather than by their tips (Figure 5(g) and Figure 5(h)).

\subsection{Area 5: Árnes in the SISZ}

Located in the SISZ, Area 5 in the island of Árnes is midway between Akbraut and Laugar, and displays prominent leakages of cold and warm water (Figures 6(a)-(j)). Its geological context is similar to Laugar, in that it is at the sites of two earthquakes, i.e., the 1896 and the 17 June 2000, and at a short distance from the Stóra-Laxá central volcano. The interglacial lava of this volcano crops out in the site of the analogue, which is surrounded by pjórsá lava and the late glacial sediments (Figure 6(a)). The older bedrock structures are identical to Laugar, with dominantly N-S dextral, ENE sinistral, and NNE rift-parallel structures, and to a lesser degree the WNW fractures. Surface ruptures of the same strike cut the younger formations of Árnes where, however, the NNE fractures are the least frequent (Figure 6(b)). 

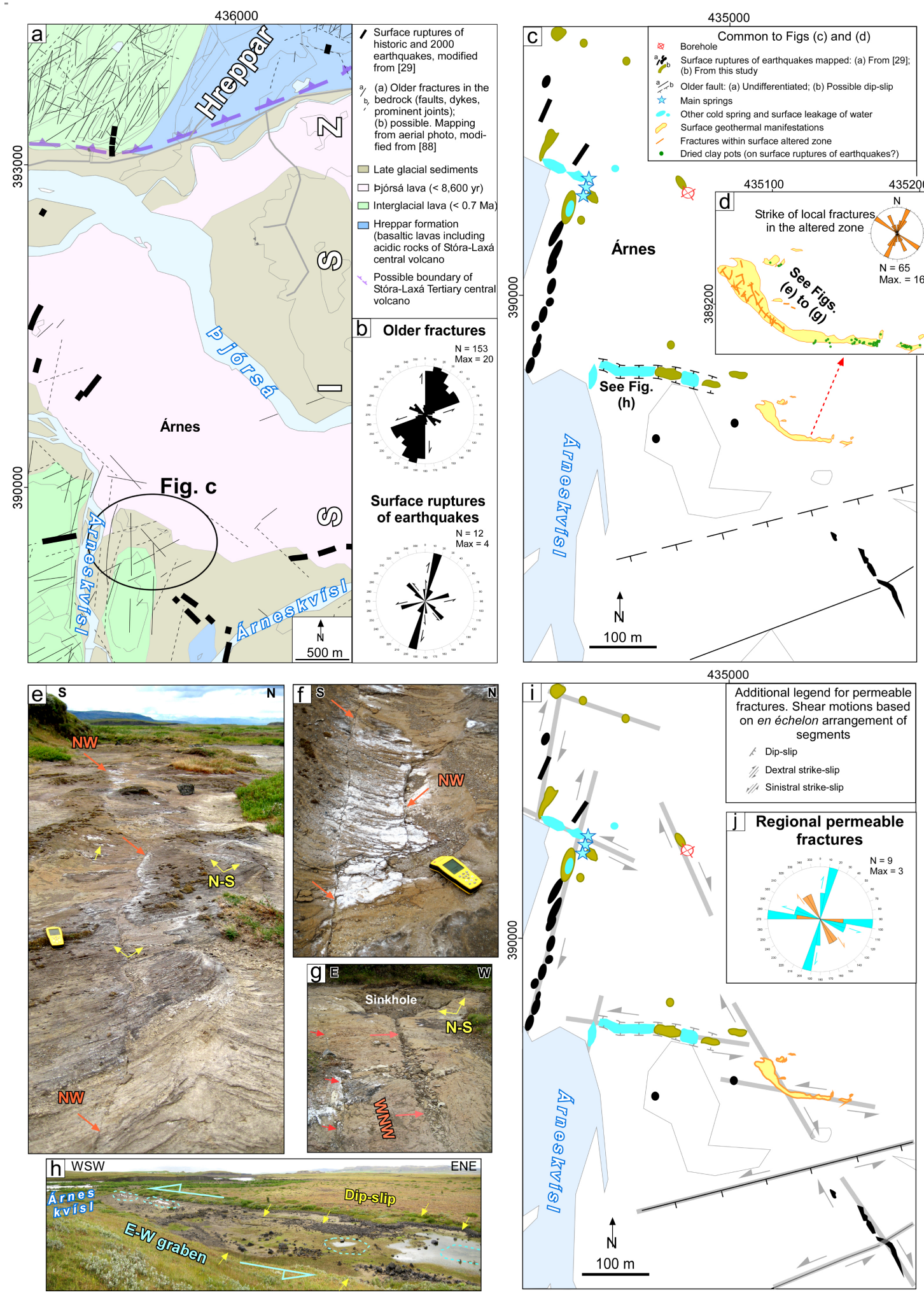

Figure 6. Area 5, Árnes in the SISZ. (a) Mapped regional stratigraphy, older and younger fractures, and the study area. (b) Rose diagrams of older and younger fractures. (c) Close-ups on geothermal manifestations, cold water leakages and surface ruptures. (d) Fracturing inside altered geothermal zones. (e) and (f) NW and N-S fractures and secondary minerals in altered geothermal zones. (g) Sinkhole, young fractures and secondary minerals in the altered geothermal zone. (h) Young graben and internal cold water leakages. (i) and (j) Highlights of leakages, permeable fracture sets, and their rose diagram. 
Area 5 is at the bend of the Árneskvísl river and the mapped features consist of surface ruptures, low temperature geothermal alteration, leakages of cold water, two ENE well-developed fractures with up to $4 \mathrm{~m}$ dip-slip, and one borehole (Figure 6(c)). The surface ruptures of the 2000 earthquakes are in two locations [29]. To the northwest, they strike N-S, have a left-stepping arrangement typical of dextral motion, and align with the river, while to the southeast they strike NW (Figure 6(c)). In this study, we mapped additional surface ruptures in the surroundings of the N-S segments, and they strike WNW, NW and E-W. Geothermal manifestations in the central part of the site are a clay zone without steam and water, that strikes NW and bends to E-W (Figure 6(c)). In the NW striking section of the alteration zone, N-S, WNW and NW secondary fractures host the alteration mineral deposition (Figures 6(d)-(g)), while in the E-W section numerous "clay pots" are similar to sinkholes of surface ruptures, and they align E-W and N-S.

The cold leakages are in two areas. One is a cluster of N-S springs in the continuation of the N-S surface ruptures, as well as WNW perpendicular to them. The other is a narrow E-W graben in the middle of the site, bounded by small E-W parallel normal faults with up to $0.5 \mathrm{~m}$ dip-slip (Figure 6(c) and Figure $6(\mathrm{~h})$ ). Within the E-W graben, there are several sinkholes filled with water and arranged in a left-stepping array typical of sinistral motion (Figure 6(h)).

Data from this site show that regardless of temperature, the permeable fracture sets are the Riedel shears of the transform zone, striking N-S dextral, E-W to WNW sinistral, and NW (Figure 6(i) and Figure 6(j)). The NW segment, however, shows evidence of dextral motion, which is opposite to the typical Riedel shears of the same strike. As this segment ruptured with the main dextral $\mathrm{N}-\mathrm{S}$ fault during the 2000 earthquakes, it is likely a splay of the main N-S source fault. The only borehole, with $\sim 50^{\circ} \mathrm{C}$, falls on this NW segment. The leakages in Area 5 occur mostly along the fracture traces although fracture intersection has contributed to local opening for the flow of cold and hot water.

\subsection{Area 6: Reykjafjall at the Intersection of SISZ and WRZ}

Area 6 in Reykjafjall (Figure 7 and Figure 8) is located at the intersection of the SISZ and the Hengill fissure swarm of the WRZ (Figure 1(b)). It is one of the sites of the 2008 earthquake doublet, and displays high temperature geothermal activity. The surface ruptures and changes in geothermal activity during this earthquake were described by [105], and some of the initial data are used here to discuss fracture permeability in the context of rift and transform zones.

Regionally, the interglacial to fini-glacial lavas, the hyaloclastites $(0.78 \mathrm{Ma}-$ $11,000 \mathrm{yrs}$ ), and the $>0.78 \mathrm{Ma}$ lavas cover Reykjafjall, while postglacial lavas $(<11,000 \mathrm{yrs})$ are in the lowland (Figure $7(\mathrm{a}))$. Bedrock faults and dykes strike NNE parallel to the rift. But they also strike N-S due to continuous seismic activity related to transform faulting, with the latest evidence during the 2008 earthquake doublet that had a mainshock on N-S structures and aftershocks on N-S and NW fractures [113] (Figure 7(b) and Figure 7(c)). 

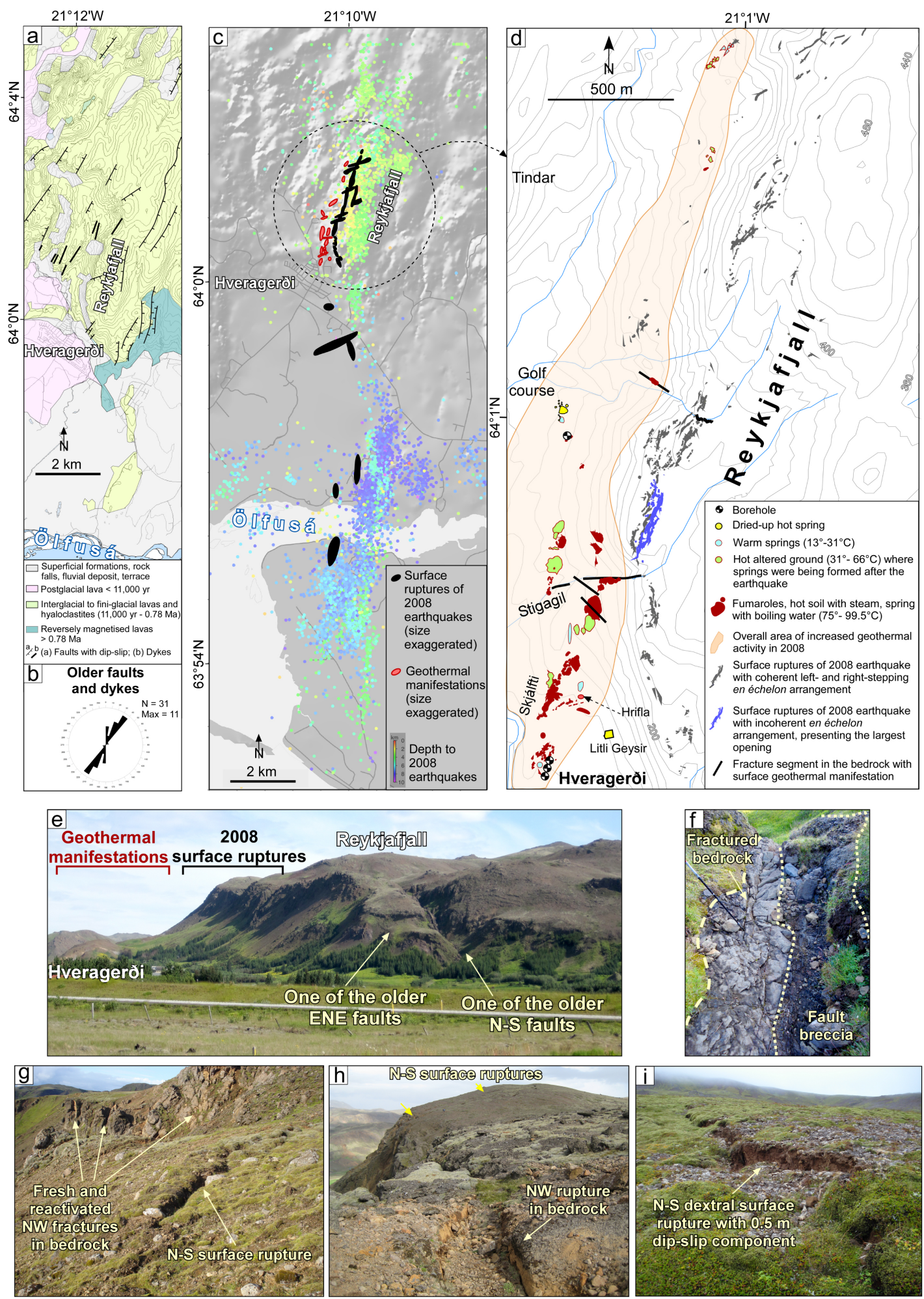

Figure 7. Area 6, Reykjafjall at the intersection of WRZ and SISZ. (a) and (b) Regional stratigraphy, older faults and dykes [121], and their rose diagram. (c) Surface ruptures and geothermal manifestations of the 2008 earthquakes (modified from [105], superimposed on the aftershocks from [113]. (d) Close-up on mapped geothermal manifestations and surface ruptures of 2008 earthquakes. (e) View on major older N-S and ENE faults in Reykjafjall, and the locations of surface ruptures and geothermal manifestations. (f) Fault breccia and secondary fractures in the bedrock. (g) to (i) Some N-S and NW oblique-slip fractures ruptured in 2008 . 

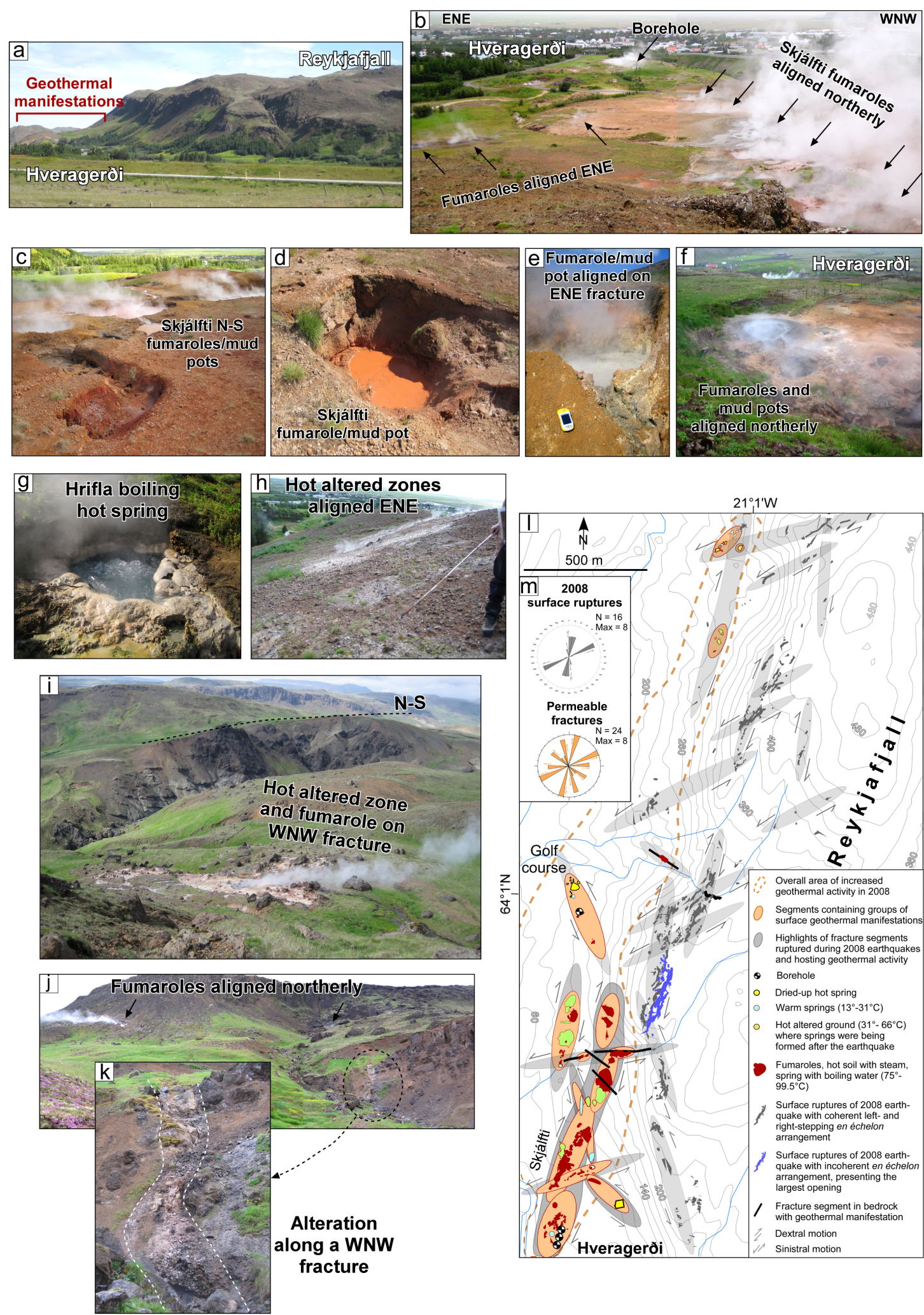

Figure 8. Area 6, Reykjafjall (continued). (a) Recall of the location of geothermal manifestations in the low land. (b) to (i) Types (fumaroles, boiling hot springs and alteration) and local alignments of geothermal manifestations. ( $\mathrm{j}$ ) and (k) Active fumaroles along N-S host surface ruptures, and mineralised fault breccia along older WNW strike-slip fault. (l) and (m) Highlights of leakages, permeable fracture sets reactivated in 2008 earthquakes, and their rose diagram. 
The mapped features in Area 6 are the surface ruptures of the 2008 earthquake located on top of Reykjafjall, a few boreholes and geothermal manifestations on the foot of Reykjafjall. The geothermal resource has been long exploited there but increased activity in this earthquake (Figure 7(d) and Figure 7(e)). The surface ruptures are in a narrow area in Reykjafjall (Figure 7(d)), and appear as linear breaks and sinkholes, arranged in left-stepping N-S and right-stepping ENE arrays typical of dextral and sinistral motions. These young structures also display dip-slips $(<1 \mathrm{~m})$ and opening Figures $7(\mathrm{~g})-(\mathrm{i}))$, indicating that they are oblique-slip fractures, but push-ups were rarely observed. A cluster of segments that ruptured during the earthquake blends with some of the N-S surface ruptures without displaying a coherent en échelon arrangement, and could represent the tearing apart of the edge of Reykjafjall. To the south, several NW-striking surface ruptures are organised in right-stepping arrays typical of sinistral motion (Figure 7(d)). It should be noted that the bedrock is also cut by older N-S and ENE faults that have up to $10 \mathrm{~m}$ dip-slips (Figure 7(e)), as well as by NW (Figure $7(\mathrm{~g})$ ), and WNW faults (Figures 8(i)-(k)), some of which have associated intense fault gouge/breccia (Figure $7(\mathrm{f})$ ). The 2008 surface ruptures are often above the older fractures and reflect reactivations of the underlying fracture sets.

In temperature, the geothermal manifestations range from hot $\left(75^{\circ} \mathrm{C}-99.5^{\circ} \mathrm{C}\right)$ to warm $\left(13^{\circ} \mathrm{C}-31^{\circ} \mathrm{C}\right)$. The metre-scale manifestations consist of fumaroles that broke the surface during the earthquake (Figures $8(\mathrm{~b})-(\mathrm{e})$ ), reactivated bursting fumaroles and mud pots (Figure 8(f)), boiling hot spring (Figure 8(g)), and soil altered by steam and fumarole (Figure $8(\mathrm{~h})$ and Figure $8(\mathrm{i})$ ). These manifestations form distinct clusters, which are wider to the south than to the north. The clusters align dominantly northerly, ENE and NW, with en échelon arrangements similar to the dextral and sinistral young surface ruptures. Additionally, a few E-W and WNW older segments filled with alteration in wide fault gouges (Figure $8(\mathrm{j})$ and Figure $8(\mathrm{k})$ ) are also present.

Although Area 6 is partially at the intersection of rift and transform zone, the data demonstrates that permeability is controlled by the N-S, ENE, NW, WNW and NW Riedel shears of the transform zone (Figure 8(l) and Figure 8(m)) that are reactivated fractures from the basement. Permeability is primarily along the traces of the younger Riedel shears, although fracture intersection enhances the flow.

\subsection{Area 7: Reykjanes in the Oblique Rift of RP}

The last outcrop analogue is Area 7 (Figures 9(a)-(j)) in the Reykjanes oblique rift, and displays high temperature geothermal activity. The area is covered by the basaltic and picrite lavas $\left(14,400\right.$ yrs to $13^{\text {th }}$ Century), and by small hyaloclastite ridges $(<0.115 \mathrm{Ma})$ (Figure $9(\mathrm{a}))$, with minimal erosion. Seismic activity related to transform faulting, without magmatism, is continuous in the area. The last two major earthquake swarms date from 1972 and 2013-2015 and both swarms show seismic lineations aligned ENE, then WNW, N-S, and E-W (Figure 9(a)). However, since late 2020, a new swarm of earthquakes with 
transform character became active in Fagradalsfjall to the east of the study area. The earthquake swarm culminated in an eruption that started on the 19 March 2021 and lasted for several months.

The features mapped in Area 7 are the bedrock fractures, the surface ruptures of earthquakes, and geothermal activity with distinct structural organisations (Figure 9(b) and Figure 9(c)). The basement faults and eruptive fissures strike dominantly NE, near the NNE strike of the rift. However, a majority of the older faults, along with a few local dykes and crater rows, strike N-S, ENE, WNW and NW (Figure 9(d) and Figure 9(e)). The younger surface ruptures are metre-scale push-ups, sinkholes and open fractures. Although their common strikes are N-S and ENE [39], they equally strike WNW and NW in Reykjanes [107]. The dip-slip of the older faults is $<0.5 \mathrm{~m}$ to $\geq 20 \mathrm{~m}$, with the highest values along ENE and N-S oblique-slip structures (Figure 9(d)), then along the NNE extensional faults. The dip-slip of the younger surface ruptures reaches up to $1 \mathrm{~m}$, and their aperture is generally $0.5 \mathrm{~m}$ (Figure $9(\mathrm{f})$ ). Both the bedrock and the younger fractures have left- and right-stepping en échelon arrangements typical of dextral motion along the N-S, WNW and NW sets, as well as sinistral motion along the ENE set (Figure 9(d)), and are thus oblique-slip.

Surface geothermal manifestations crop out in an area of $\sim 1 \times 2 \mathrm{~km}$ (Figure 9(b) and Figure 9(c)), considered to be above the centre of the geothermal reservoir into which 37 wells $<3 \mathrm{~km}$ were drilled, and the IDDP-2 well was deepened to $4.5 \mathrm{~km}$ depth reaching $>400^{\circ} \mathrm{C}$ [114]. The mapped manifestations range from $99^{\circ} \mathrm{C}$ to $11^{\circ} \mathrm{C}$, and they consist of intense to minimally altered soil, fumaroles, steam vents, bursting mud pots, and green moss with steam escaping from fractures (Figure 9(b) and Figures 9(f)-(i)). Fumaroles and mud pots are generally $<1 \mathrm{~m}$ in diameter, but the biggest ones at Gunnuhver are $2.5 \mathrm{~m}$ diameter, strongly venting water and steam (Figure 9(i)).

Several features emerge from Area 7 (Figure 9(j)). First, two ENE sinistral oblique-slip fractures (L and G on Figure 9(j)) act as the boundary of the geothermal reservoir. Regional craters arranged in an ENE en échelon array appear farther to the east-northeast and fall on the continuation of the southern reservoir boundary fault, indicating that magma injects also into oblique-slip faults [107]. Second, the shear fractures and the few NNE extensional structures compartmentalise together the reservoir into smaller blocks. Within the reservoir, geothermal manifestations align dominantly on the main ENE, N-S and WNW/NW oblique-slip segments (Figure $9(j)$ ). Furthermore, the analysis of tracer recovery in wells has shown that one ENE sinistral and one N-S dextral oblique-slip fractures in the middle of the reservoir act alternatively as carrier and barrier structures to the flow, depending on the direction of incoming injected water [107]. Rift-parallel structures have been favoured as flow paths for geothermal fluid and magma. However, the bulk of data shows that fracture permeability is controlled by the oblique-slip Riedel sets of the transform zone where leakages are mostly along the fractures although opening at fracture intersections increases the fluid flow. 

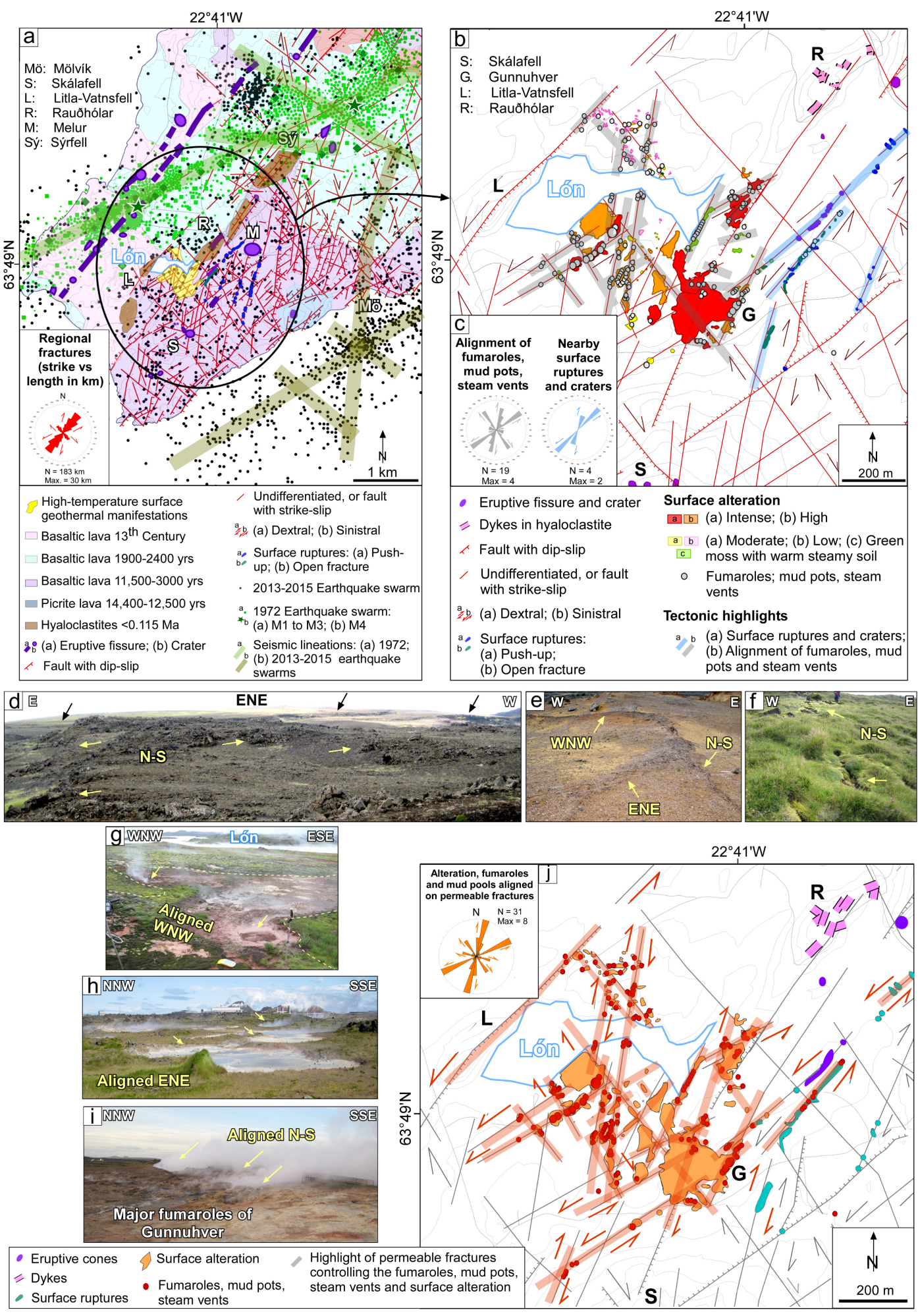

Figure 9. Area 7, Reykjanes in the oblique rift. (a) Regional stratigraphy [95], older oblique-slip faults and their rose diagram, eruptive fissures, surface ruptures of earthquakes [107], 1972 and 2013-2015 earthquake swarms [103] [104]. (b) and (c) Mapped geothermal manifestations, older oblique-slip faults and dykes, surface ruptures, and their rose diagrams. (d) to (f) Segmented ENE and N-S oblique-slip faults, dykes, and surface ruptures with geothermal manifestations. (g) to (i) Surface geothermal manifestations and their left- and right-stepping en échelon arrangements. (j) Highlights of leakages, permeable fracture sets, and their rose diagram. 


\section{Interpretation}

\subsection{Permeable Fractures, Earthquakes and Tectonic Regimes}

Figures 10(a)-(g) compile the strikes of older regional fractures, the young surface ruptures, and the permeable fractures of each study area, along with a quick correlation with literature data regarding earthquakes [101] [103] [104] [109] [113] [115] and stress fields [91]. Having in mind that the structures in the 7 studied areas are at different stages of tectonic evolution, they can be interpreted as follows.

The structures in Area 1 (Figure 10(a)) are in an older crust, which formed over millions of years at the plate boundaries and shifted away. These bedrock fractures are reactivated since the Quaternary volcanism was emplaced, and presently undergo occasional intraplate earthquakes. The density and strike-range of basement fractures are much wider, so are the peaks of the most frequent sets (NNE to NE and ENE to WNW). The reactivated fractures hosting all the regional geothermal manifestations strike dominantly northerly, NW, ENE, and WNW. The same permeable fractures are found in the area to the south of the geothermal system but with different frequencies. It is noted that the permeable fracture sets do not reflect the dominant ENE seismic lineations of the 1974 earthquake swarms that occurred at some $10 \mathrm{~km}$ distance, but they fit with the fault plane solutions (FPS) of those events. The stress fields proposed by [91] show a dominant normal fault regime compared to strike-slip regime, with severe fluctuations in the direction of Shmax (Figure 10(a)). Similar fluctuations in the paleostresses were observed in various parts of West Iceland, e.g. [89] [116], as much as in the FPS of the single 1974 earthquake event.

The structures in Areas 2 to 7 are at a younger stage of tectonic evolution as they are still being formed and reactivated within the active plate boundaries under frequent earthquakes (Figures 10(b)-(g)), thus not fully developed and with a narrower strike-range than bedrock structures. Both among the bedrock and the surface ruptures, the dominant structures are the N-S and ENE, then WNW and NW oblique-slip fractures, and secondarily the NNE rift-parallel structures. Albeit with slight differences in frequency, the same sets control the permeability of cold and hot water, be it within the SISZ transform fault (Areas 2 to 5), at the intersection of rift and transform zones (Area 6), or at the oblique rift (Area 7). The mapped bedrock, younger, and permeable fractures also correlate well with earthquake data, namely the seismic lineations and the FPS of the 2000 earthquakes in Areas 2 to 5 (Figures 10(b)-(e)), the 2008 earthquake in Area 6 (Figure 10(f)), and the earthquake swarms in Area 7 (Figure 10(g)). In terms of stress fields, strike-slip regime is dominant in Areas 2 to 5 and 7, with slight fluctuations in the direction of Shmax, but no defined stress regime and Shmax are proposed covering Area 6 [91].

\subsection{Fracture Geometry and Compatible Stresses}

All mapped cold and hot water leakages, and their host fractures, are reported 

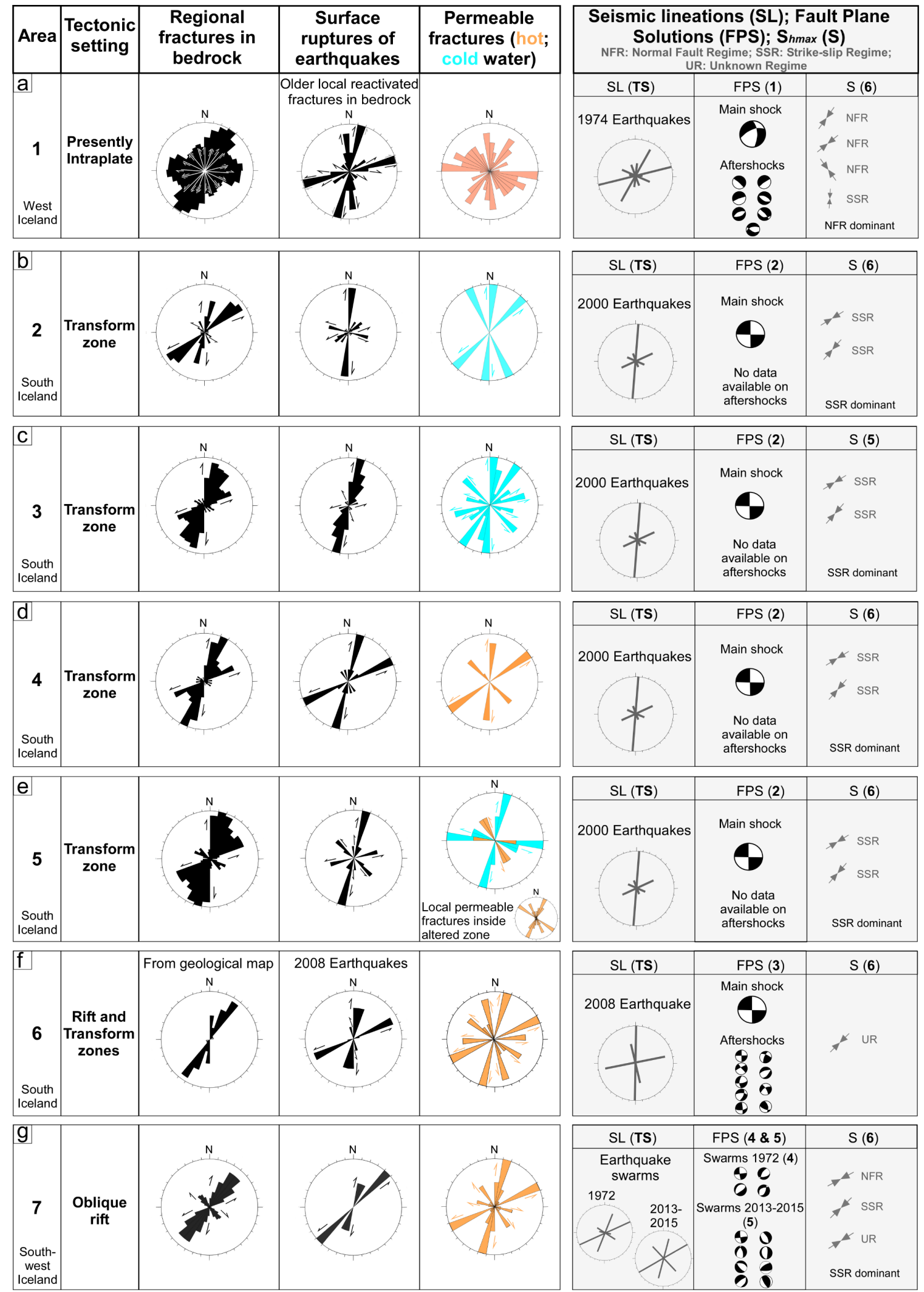

Figure 10. (a) to (g) Rose diagrams of regional fractures in the bedrocks, surface ruptures, and permeable fracture sets in the 7 studied areas, and correlation with earthquakes and stress data. The interpretations of Seismic Lineations are from this study (TS). The regional fractures in bedrock on (f) are from [121]. The fault plane solutions are: (FPS1) from [109], (FPS2) from [113], (FPS3) from [115], (FPS4) from [101], (FPS5) from [103] [104]. The directions of Shmax (S6) are from [91]. 
on Figures 11(a)-(g)) for an overview of their geometries. Using the simple shear model, attempts were also made to deduce the directions of maximum $\left(\sigma_{1}\right)$ and minimum $\left(\sigma_{3}\right)$ principal stresses compatible with the permeable fractures of each area, unrelated to the regional stress fields and regimes proposed by [91].

In the intraplate Area 1 (Figure 11(a)), permeable fractures fall in the continuation of older structures of the same strikes in the immediate bedrock, which have developed over millions of years, coalesced into longer structures, and lost their initial en échelon geometries. Regardless of temperatures, the leakages align along the main NW, N-S, NE/ENE and WNW oblique-slip fractures rather than by their tips. They also appear as much along the main fractures as at the fracture intersections, with no major difference in the volume of the flow. As a result of their long-term activity and reactivations, older fractures of the same set sometimes show opposite sense of motions, thus incompatible with a single stress field. Therefore, at least two sets of stress fields are required to explain all the mapped structures in this area. One set would be with a NNE $\sigma_{1}$ and WNW $\sigma_{3}$, compatible with N-S to NW dextral and NE to ENE sinistral oblique-slip faults. Another set would be with a NNW $\sigma_{1}$ and ENE $\sigma_{3}$, compatible with the WNW dextral oblique-slip fractures that are parallel to the Quaternary WNWstriking dextral SVZ.

The fracture geometries and the stress fields differ in Areas 2 to 7 within the active plate boundaries (Figures 11(b)-(g)). The majority of the dominant oblique-slips, and the less frequent NNE rift-parallel permeable fractures still present en échelon arrangements, indicating that they are surface expression of deeper structures. In these areas, the leakages are primarily along and in the middle section of the main fractures or on their splays (e.g., Areas 5 and 7), rather than by the fracture tips or in the stepovers between segments. Occasionally, leakages are at the fracture intersections.

In Areas 2 to 7, where the transform segment is a regional shear zone, the permeable fractures act as its internal Riedel shears, accommodating the overall sinistral motion of the transform zone. They are the main N-S to NNW dextral (R') and ENE to E-W sinistral (R) conjugate sets, the second order shear fractures striking WNW to NW sinistral (P), and occasionally the NNW (X) also possibly sinistral. The NNE/NE extensional fractures represent $(\mathrm{T})$ within the transform zone and are the main rift-parallel fractures outside of the shear zone. The literature agrees that the transform zone is overall ENE in Reykjanes, and considers the transform zone to be $\mathrm{E}-\mathrm{W}$ in South Iceland (Figure 1). A recent multidisciplinary analysis at the scale of South Iceland, however, demonstrates that the transform zone likely trends ENE also in South Iceland [88], which explains why the internal permeable Riedel shears have the same strike-ranges and overall motions in Areas 2 to 7. Despite slight fluctuations, the principal stresses compatible with a regional ENE shear zone and its internal Riedel shears would be a NE $\sigma_{1}$ and a NW $\sigma_{3}$, applicable to all areas.

Another point to address is the dextral motion of the WNW and NW sets in Areas 5 and 7 (Figures 11(e)-(g)). In Area 5, the NW dextral permeable fracture 

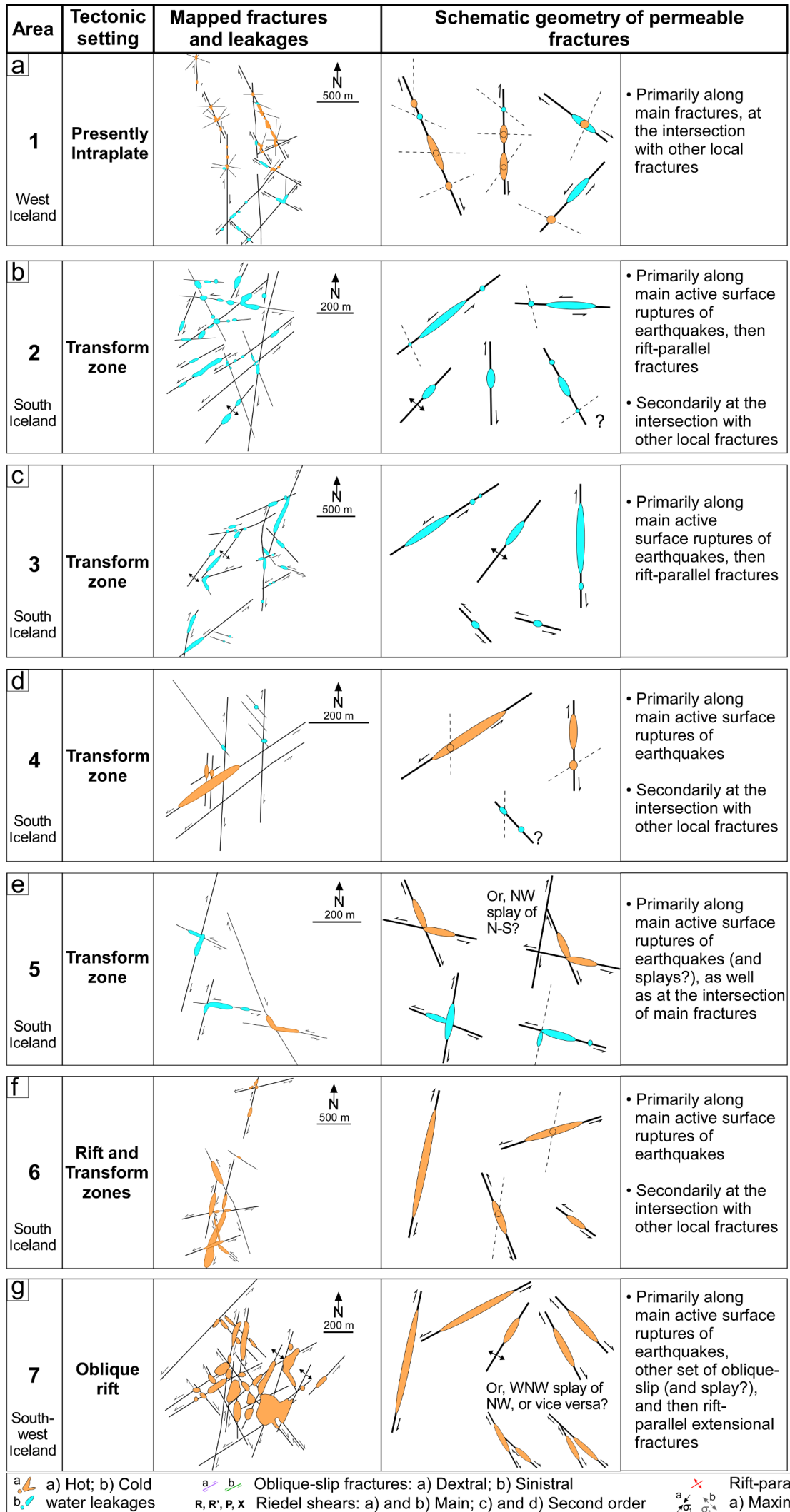

$\mathbf{R}, \mathbf{R}^{\prime}, \mathbf{P}, \mathbf{X}$ Riedel shears: a) and b) Main; c) and d) Second order

\section{Permeable fracture sets and compatible stress}

- Dominantly strike-slip: NNW, NW, and N-S dextral; NE and ENE sinistral
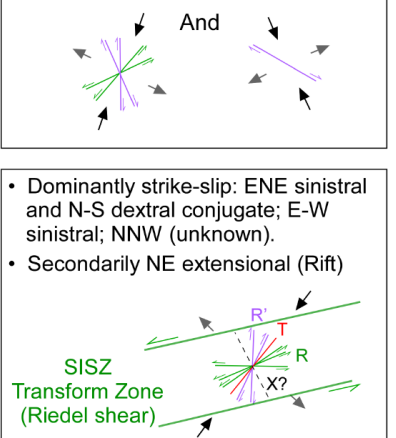

\section{- Dominantly strike-slip: N-S dextral} and ENE sinistral conjugate; WNW sinistral.

- Secondarily NE extensional (Rift)

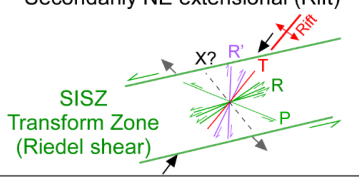

- Dominantly strike-slip: ENE sinistral and N-S dextral; WNW (unknown)
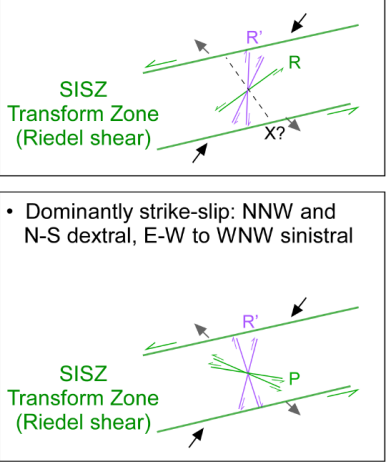

- Dominantly strike-slip: N-S dextral and ENE sinistral conjugate; NW sinistral; WNW (unknown)

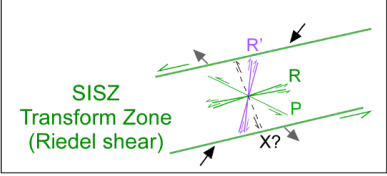

- Dominantly strike-slip: ENE sinistral and N-S dextral conjugate; WNW and NW dextral

- Secondarily NNE extensional (Rift)

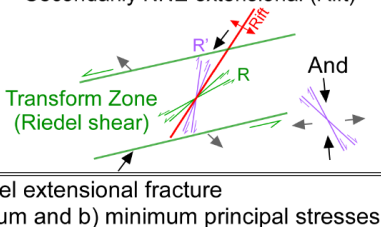

Figure 11. (a) to (g) Interpretations of the geometry of permeable fractures, as well as the maximum $\left(\sigma_{1}\right)$ and minimum principal $\left(\sigma_{3}\right)$ stresses compatible with the fracture patterns of the 7 studied areas within the active plate boundaries and the intraplate contexts. Note the dominance of oblique-slip permeable fractures. 
that ruptured alongside the main N-S dextral source fault during the 2000 earthquakes could be a splay of this latter, both compatible with the same stress field. In Area 7 within the Reykjanes oblique-rift, however, the WNW and NW permeable sets are more complex and their origin is still a matter of debates in the literature. The NW set could be a splay of the WNW set, or vice versa, but these fractures are dextral, highly frequent and well developed compared to the typical sinistral Riedel shears (P). Thus, they likely represent a separate system. Similar to the WNW dextral permeable shear fractures in Area 1, they require an additional set of stresses with a northerly $\sigma_{1}$ and an E-W $\sigma_{3}$ in Reykjanes (Figure 11(g)).

\section{Summary and Concluding Remarks}

We investigated the fracture permeability in 7 areas where structures are at different stages of tectonic evolution (Figures 2-11). In West Iceland (Area 1), the crust formed at the Tertiary plate boundaries (16 - 15 to $\sim 3 \mathrm{Ma}$ ) and shifted to an intraplate position. By contrast, the crust and its structures are younger (3.4 $\mathrm{Ma}$ - present) and undergo intense deformation within the active transform zone of SISZ (Areas 2 to 5), at the intersection of rift and transform zones (Area 6), and in the Reykjanes oblique rift (Area 7). Our results bring new insights into the tectonic control of cold and hot leakages within an oceanic crust at diverging plate boundaries. The three main findings concern, 1) the permeable fracture sets and compatible stresses, 2) fracture geometries, 3) the structural flow paths (Figure 12):

1) Whether in bedrock or in the younger crust, the permeable fractures group into six sets (Figure 12(a)). All sets display dip-slip but five of them have shear motions and are thus oblique-slip. In the intraplate Area 1, the permeable sets are dominantly N-S to NNW dextral and ENE sinistral oblique-slip fractures, and secondarily WNW dextral fractures parallel to the Quaternary intraplate dextral SVZ. The three permeable sets are at some distance from the site of 1974 earthquakes and fit only partially with the FPS of those intraplate events. In Areas 2 to 7, the oblique-slip permeable fracture sets are identical to surface ruptures of earthquakes, acting as the Riedel shears of the ENE sinistral transform zone crossing those areas. The sets are the main N-S to NNW dextral (R') and ENE to E-W sinistral (R) conjugate fractures, the second order WNW to NW sinistral (P), and occasionally the NNW (X) likely also sinistral. Within the transform zone, the NNE/NE set acts as the extensional fracture ( $\mathrm{T}$ ), but outside the shear zone it is the main rift-parallel set. The oblique-slip Riedel shears fit the FPS of earthquakes in those active areas [103] [104] [106] [113] [115]. The NW and WNW permeable sets display dextral motions in two areas. In Area 5, the NW set could be the splay of the main N-S source fault, both of which ruptured during the 2000 earthquakes. In Area 7, the NW and WNW could be alternatively splay of each other. However, they belong likely to a separate fracture system as they are widespread, highly developed and with a sense of motion 

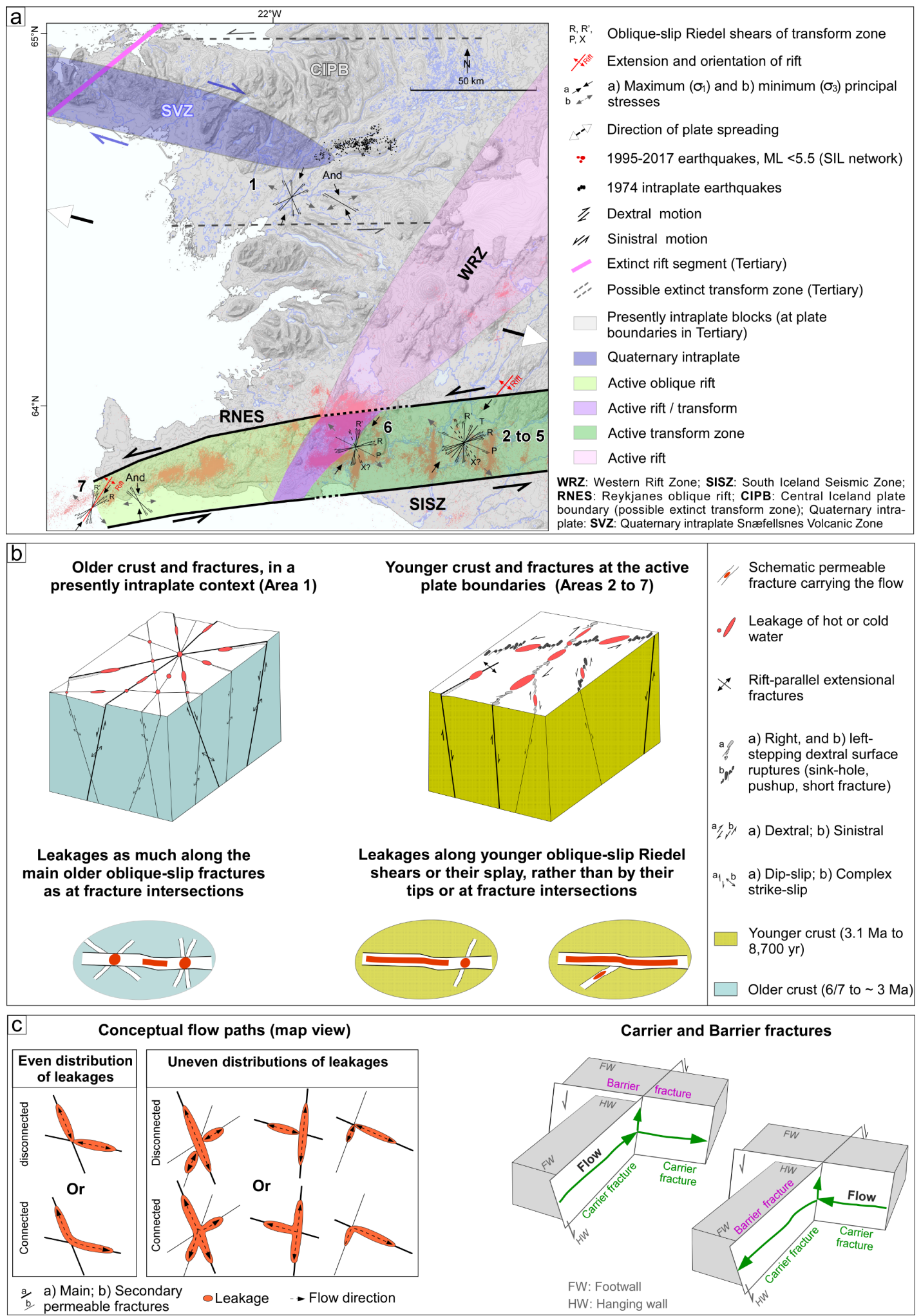

Figure 12. Summary and conclusions. (a) Dominantly oblique-slip permeable fractures and compatible stresses in the 7 studied areas in the intraplate context of West Iceland and within the active plate boundaries in the South and Southwest of Iceland. (b) Fracture geometry in the older crust filled with secondary minerals where more fracture intersections are needed for permeability, and in the younger crust where fractures are more open and leakages occur along the main segments and their splays. (c) Postulated flow paths and concept of carrier and barrier structures in case of intersecting fractures. 
opposite to typical Riedel shears (P). Based on the simple shear model, the principal stresses compatible with the typical Riedel shears of Areas 2 to 7 within the active plate boundaries would be a NE $\left(\sigma_{1}\right)$ and a NW $\left(\sigma_{3}\right)$. In intraplate Area 1, they would be NNE $\left(\sigma_{1}\right)$ and a WNW $\left(\sigma_{3}\right)$. Additional sets are required to explain the WNW to NW dextral permeable fractures, which would be a N-S $\left(\sigma_{1}\right)$ and an E-W $\left(\sigma_{3}\right)$ in Area 7, and a NNW $\left(\sigma_{1}\right)$ and an ENE $\left(\sigma_{3}\right)$ in Area 1. The obtained principal stresses neither address the fluctuations per locations as observed by [91], or the opposite sense of motions along the same sets [81] [89], nor the complex regional paleostresses, e.g. [116]. Our results simply reflect the present-day dynamics under which fractures are opened for fluid flow. As leakages are dominantly along oblique-slip fractures, permeability is primarily controlled by transform faulting and secondarily by rifting.

2) Area 1 formed at active plate boundaries, shifted into intraplate position, and is eroded down to $1.5 \mathrm{~km}$. Over millions of years, fractures developed from their original young en échelon arrangements above deeper structures within active plate boundaries, coalesced and grew into longer fractures that have now fully broken the surface (Figure 12(b)). During their lifetime, the crust and the fractures filled with secondary minerals, thus decreasing the permeability. Reactivation of fractures under the latest tectonic stresses allows leakages along the main fractures as much as at the intersection with other local structures. However, in absence of frequent earthquakes and with a decreased permeability, leakages are inconspicuous, and a higher number of fracture intersections is needed for local opening to fluid flow. By contrast, in active Areas 2 to 7 (Figure 12(b)), the younger oblique-slip fractures, with dominantly en échelon arrangements, are not fully filled with secondary minerals and remain open under intense earthquake activity. There, the leakages are more voluminous and located primarily along the main structures and their splay rather than by fracture tips, in the stepovers, or at fracture intersections. One reason why stepovers are not dominant permeable zones in these analogues might be that structures are in a thin oceanic crust, and develop rapidly within plate boundaries from their original en échelon arrangement into longer coalesced fractures. This is in contrast to the examples from overseas, e.g. [46] [53], where structures are mostly in thick continental crust, plate boundaries develop over longer period of time period, preserving fracture geometries.

3) Although the flow directions are unknown, some remarks can be made when leakages present an even or uneven distribution at fracture intersections (Figure 12(c)). Fluid flows are both vertical and horizontal, but only horizontal flow is considered here on map views. When leakages are evenly distributed on two main intersecting fractures, the fluid could either be flowing in a disconnected manner along each of the main structures, or via the point of intersection into both structures (connected). The same connectivity and dysconnectivity also apply to asymmetric distribution of leakages where the volume is higher along the main fracture than on the intersecting structure. These configurations can be 
partially explained by the concept of carrier and barrier structures to the flow (Figure 12(c)), which was first proposed in Iceland by analysing the tracer recoveries in wells from Reykjanes [117] and Húsmúli in Hengill [118]. In case of intersecting fractures, the criteria that determine which fracture is a carrier or a barrier are: a) the strike of the fracture compared to the direction of fluid flow; b) the dip direction of the fracture; c) whether the incoming fluid is on the hanging wall or the footwall of a fault.

This study shows the role of tectonics in fracture permeability, block compartmentalisation and fluid flow, where the key is to distinguish which mechanism governs the permeability. Although Iceland is known as an example of extensional plate boundary, the analogues demonstrate that transform mechanism controls the permeability, with dominantly oblique-slip regional and local permeable sets, regardless of age of the structures or the temperature of the leakages.

\section{Acknowledgements}

The initial data used in this paper were collected during a long-term cooperative project funded by Landsvirkjun (National Power Company of Iceland), Orkuveita Reykjavíkur (Reykjavík Energy) and Orkustofnun (National Energy Authority), and while Maryam Khodayar was a staff member of Iceland GeoSurvey (ÍSOR). We wish to thank the above sponsors for commissioning the data collection, analyses and interpretations that were carried out for geothermal exploration, as well as seismic hazards for hydropower projects. We also thank the sponsors for their permissions to publish the results in papers. The preparation of this paper was supported by the Energy Research Fund of Landsvirkjun (Grants 2020 and 2021). The authors wish to thank the anonymous reviewers for their helpful comments. At the Open Journal of Geology, we thank Joanna Cheng (Managing Editor) for her invaluable support and assistance, and the publishing department for their efforts to publish high quality figures.

\section{Conflicts of Interest}

The authors declare no conflicts of interest regarding the publication of this paper.

\section{References}

[1] Rivas, J.A., Castellón, J.A. and Maravilla, J.N., (2005) Seven Years of Reservoir Seismic Monitoring at Berlin Geothermal Field, Usulután, El Salvador. Proceedings World Geothermal Congress, Antalya, 24-29 April 2005, 8 p.

[2] Sibson, R.H. (1996) Structural Permeability of Fluid-Driven Fault-Fracture Meshes. Journal of Structural Geology, 18, 1031-1042. https://doi.org/10.1016/0191-8141(96)00032-6

[3] Harding, T.P., Vierbuchen, R.C. and Christie-Blick, N. (1985) Structural Styles, Plate-Tectonic Settings, and Hydrocarbon Traps of Divergent (Transtensional) Wrench Faults. In: Biddle, K.T. and Christie-Blick, N., Eds., Strike-Slip Deforma- 
tion, Basin Formation, and Sedimentation, SEPM Special Publications, Tulsa, 51-77. https://doi.org/10.2110/pec.85.37.0051

[4] Curewitz, D. and Karson, J.A. (1997) Structural Settings of Hydrothermal Outflow: Fracture Permeability Maintained by Fault Propagation and Interaction. Journal of Volcanology and Geothermal Research, 79, 149-168. https://doi.org/10.1016/S0377-0273(97)00027-9

[5] Ziegler, P.A., and Cloetingh, S. (2004) Dynamic Processes Controlling Evolution of Rifted Basins. Earth-Science Reviews, 64, 1-50. https://doi.org/10.1016/S0012-8252(03)00041-2

[6] Faulds, J.E., Coolbaugh, M., Bouchot, V., Moeck, I., and Oguz, K. (2010) Characterizing Structural Controls of Geothermal Reservoirs in the Basin and Range, USA, and Western Turkey: Developing Successful Exploration Strategies in Extended Terranes. Proceedings of the World Geothermal Congress, Bali, 25-29 April 2010, $11 \mathrm{p}$.

[7] Delvaux, D. (2001) Tectonic and Palaeostress Evolution of the Tanganyika-RukwaMalawi Rift Segment, East African Rift System. In: Ziegler, P.A., Cavazza, W., Robertson, A.H.F. and Crasquin-Soleau, S., Eds., Peri-Tethys Memoir 6: Peri Tethyan Riftl Wrench Basins and Passive Margins, Vol. 186, Mémoire de la Musée National d'Histoire Naturelle, Paris, 545-567.

[8] Davatzes, N.C. and Hickman, S.H. (2006) Stress and Faulting in the Coso Geothermal Field: Update and Recent Results from the East Flank and Coso Wash. Proceedings of the 31 st Workshop on Geothermal Reservoir Engineering, Stanford, 30 January-1 February 2006, 12 p.

[9] Fossen, H. (2010) Structural Geology. Cambridge University Press, Cambridge. https://doi.org/10.1017/CBO9780511777806

[10] Perez-Flores, P., Veloso, E., Cembrano, J., Sanchez-Alfaro, P., Lizama, M. and Arancibia, G. (2017) Fracture Network, Fluid Pathways and Paleostress at the Tolhuaca Geothermal Field. Journal of Structural Geology, 96, 134-148. https://doi.org/10.1016/j.jsg.2017.01.009

[11] Moeck. I., Kwiatek, G. and Zimmerman, G. (2009) Slip Tendency Analysis, Fault Reactivation Potential and Induced Seismicity in a Deep Geothermal Reservoir. Journal of Structural Geology, 31, 1174-1182. https://doi.org/10.1016/j.jsg.2009.06.012

[12] Brosch, F.J. and Pischinger, G. (2014) Small-to Meso-Scale Brittle Rock Structures and the Estimation of "Paleostress" Axes-A Case Study from the Koralm Region (Styria/Carinthia). Austrian Journal of Earth Sciences, 107, 37-59.

[13] Dyer, B.C., Schanz, U., Spillmann, T. Ladner, F. and Häring, M.O. (2010) Application of Microseismic Multiplet Analysis to the Basel Geothermal Reservoir Stimulation Events. Geophysical Prospecting, 58, 791-807. https://doi.org/10.1111/j.1365-2478.2010.00902.x

[14] Evans, K.F., Zappone, A., Kraft, T., Deichmann, N. and Moia, F. (2012) A Survey of the Induced Seismic Responses to Fluid Injection in Geothermal and CO2 Reservoirs in Europe. Geothermics, 41, 30-54. https://doi.org/10.1016/j.geothermics.2011.08.002

[15] Ellsworth, W.L., Giardini, D., Townend, J., Ge, S.M. and Shimamoto, T. (2019) Triggering of the Pohang, Korea, Earthquake (Mw 5.5) by Enhanced Geothermal System Stimulation. Seismological Research Letters, 90, 1844-1858. https://doi.org/10.1785/0220190102

[16] Keilegavlen, E., Duboeuf, L., Dichiarante, A. M., Halldórsdóttir, S., Stefansson, I., 
Naumann, M., Guðnason, E.Á., Ágústsson, K., Eggertsson, G.H., Oye, V. and Berre, I. (2021) Hydro-Mechanical Simulation and Analysis of Induced Seismicity for a Hydraulic Stimulation Test at the Reykjanes Geothermal Field, Iceland. Geothermics, 97, Article ID: 102223. https://doi.org/10.1016/j.geothermics.2021.102223

[17] Cole, J.W. (1990) Structural Control and Origin of Volcanism in the Taupo Volcanic Zone, New Zealand. Bulletin of Volcanology, 52, 445-459. https://doi.org/10.1007/BF00268925

[18] Wilson, C.J.N. and Rowland, J.V. (2016) The Volcanic, Magmatic and Tectonic Setting of the Taupo Volcanic Zone, New Zealand, Reviewed from a Geothermal Perspective. Geothermics, 59, 168-187.

https://doi.org/10.1016/j.geothermics.2015.06.013

[19] Wilson, J.T. (1965) A New Class of Faults and Their Bearing on Continental Drift. Nature, 207, 343-347. https://doi.org/10.1038/207343a0

[20] Morley, C.K., Nelson, R.A., Patton, T.L. and Munn, S.G. (1990) Transfer Zones in the East African Rift System and Their Relevance to Hydrocarbon Exploration in Rifts. AAPG Bulletin, 74, 1234-1253. https://doi.org/10.1306/0C9B2475-1710-11D7-8645000102C1865D

[21] Gawthorpe, R.L. and Hurst, M. (1993) Transfer Zones in Extensional Basins: Their Structural Style and Influence on Drainage Development and Stratigraphy. Journal of the Geological Society, 150, 1137-1152. https://doi.org/10.1144/gsigs.150.6.1137

[22] Vine, F.J. (1966) Spreading of the Ocean Floor: New Evidence. Science, 154, 1405-1415. https://doi.org/10.1126/science.154.3755.1405

[23] Talwani, M. and Eldholm, O. (1977) Evolution of the Norwegian-Greenland Sea. Geological Society of America Bulletin, 88, 969-999. https://doi.org/10.1130/0016-7606(1977)88<969:EOTNS >2.0.CO;2

[24] Withjack, M.O. and Jamison, W.R. (1986) Deformation Produced by Oblique Rifting. Tectonophysics, 126, 99-124. https://doi.org/10.1016/0040-1951(86)90222-2

[25] Freund, R. (1970) Rotation of Strike-Slip Faults in Sistan, Southeastern Iran. Journal of Geology, 78, 188-200. https://doi.org/10.1086/627500

[26] Ron, H., Freund, R., Garfunkel, Z. and Nur, A. (1984) Block Rotation by Strike-Slip Faulting: Structural and Paleomagnetic Evidence. Journal of Geophysical Research, 89, 6256-6270. https://doi.org/10.1029/JB089iB07p06256

[27] Cowan, D.S., Botros, M. and Johnson, H.P. (1986) Bookshelf Tectonics: Rotated Crustal Blocks within the Sovanco Fracture Zone. Geophysical Research Letters, 13, 995-998. https://doi.org/10.1029/GL013i010p00995

[28] Bird, R.T., Naar, D., Larson, R.L., Searle, R.C. and Scotese, C.R. (1998) Plate Tectonic Reconstructions of the Juan Fernandez Microplate: Transformation from Internal Shear to Rigid Rotation. Journal of Geophysical Research, 103, 7049-7067. https://doi.org/10.1029/97JB02133

[29] Einarsson, P. (2008). Plate Boundaries, Rifts and Transforms in Iceland. Jökull, 58, $35-58$.

[30] Tapponnier, P., Armijo, R., Manighetti, I. and Courtillot, V. (1990) Bookshelf Faulting and Horizontal Block Rotations between Overlapping Rifts in Southern Afar. Geophysical Research Letters, 17, 1-4. https://doi.org/10.1029/GL017i001p00001

[31] Morgan, J.P. and Kleinrock, M.C. (1991) Transform Zone Migration: Implications of Bookshelf Faulting at Oceanic and Icelandic Propagating Ridges. Tectonics, 10, 920-935. https://doi.org/10.1029/90TC02481

[32] Fossen, H. and Tikoff, B. (1998) Extended Models of Transpression and Transten- 
sion, and Application to Tectonic Settings. In: Holdsworth, R.E., Strachan, R.A. and Dewey, J.F., Eds., Continental Transpressional and Transtensional Tectonics. Geological Society, 135, 15-33. https://doi.org/10.1144/GSL.SP.1998.135.01.02

[33] Huchon, P. and Khanbari, K. (2003) Rotation of the Syn-Rift Stress Field of the Northern Gulf of Aden Margin, Yemen. Tectonophysics, 364, 147-166. https://doi.org/10.1016/S0040-1951(03)00056-8

[34] Homberg, C., Bergerat, F., Angelier, J. and Garcia, S. (2010) Fault Interaction and Stresses along Broad Oceanic Transform Zone: Tjörnes Fracture Zone, North Iceland. Tectonics, 29, TC1002. https://doi.org/10.1029/2008TC002415

[35] Garfunkel, Z. (1981) Internal Structure of the Dead Sea Leaky Transform (Rift) in Relation to Plate Kinematics. Tectonophysics, 80, 81-108.

https://doi.org/10.1016/0040-1951(81)90143-8

[36] Hayward, N.J. and Ebinger, C.J. (1996) Variations in the Along-Axis Segmentation of the Afar Rift system. Tectonics, 15, 244-257. https://doi.org/10.1029/95TC02292

[37] Lawrence, R.M., Karson, J.A. and Hurst, S. (1998) Dike Orientations, Fault-Block Rotations, and the Construction of Slow Spreading Oceanic Crust at $22^{\circ} 40^{\prime} \mathrm{N}$ on the Mid-Atlantic Ridge. Journal of Geophysical Research, 103, 663-676.

https://doi.org/10.1029/97JB02541

[38] Dauteuil, P. and Brun, J.P. (1996) Deformation Partitioning in a Slow-Spreading Ridge Undergoing Oblique Extension (Mohns Ridge-Norwegian Sea). Tectonics, 15, 870-884. https://doi.org/10.1029/95TC03682

[39] Clifton, A.E. and Schlische, R.W. (2003) Fracture Populations on the Reykjanes Peninsula, Iceland: Comparison with Experimental Clay Models of Oblique Rifting. Journal of Geophysical Research B: Solid Earth, 108, ETG 4-1-ETG 4-17.

[40] Laughton, A.S. and Searle, R.C. (1979) Tectonic Processes on Slow-Spreading Ridges. In: Talwani, M., Harrison, C.G. and Hayes, D.E., Eds., Deep Drilling Results in the Atlantic Ocean: Ocean Crust. Maurice Ewing Series, Vol. 2, American Geophysical Union, 15-32. https://doi.org/10.1029/ME002p0015

[41] Corti, G. (2009) Continental Rift Evolution: From Rift Initiation to Incipient Break-Up in the Main Ethiopian Rift, East Africa. Earth Science Reviews, 96, 1-53. https://doi.org/10.1016/j.earscirev.2009.06.005

[42] Tchalenko, J.S. (1970) Similarities between Shear Zones of Different Magnitude. Geological Society of America Bulletin, 81, 1625-1640. https://doi.org/10.1130/0016-7606(1970)81[1625:SBSZOD]2.0.CO;2

[43] Aydin, A. and Nur, A. (1982) Evolution of Stepover Basins and Their Scale Independence. Tectonics, 1, 91-105.

[44] Mann, P., Hempton, M.R., Bradley, D.C. and Burke, K. (1983) Development of Pull-Apart Basins. Journal of Geology, 91, 529-554. https://doi.org/10.1086/628803

[45] Woodcock, N.H., and Fischer, M. (1986) Strike-Slip Duplexes. Journal of Structural Geology, 8, 725-735. https://doi.org/10.1016/0191-8141(86)90021-0

[46] Aydin, A. and Nur, A. (1985) The Types and Role of Stepovers in Strike Slip Tectonics. In: Biddle, K.T. and Christie-Blick, N., Eds., Strike-Slip Deformation, Basin Formation, and Sedimentation. Society of Economic Paleontologists and Mineralogists, 37, 35-44. https://doi.org/10.2110/pec.85.37.0035

[47] Ben-Avraham, Z. and Zoback, M.D. (1992) Transform-Normal Extension and Asymmetric Basins: An Alternative to Pull-Apart Models. Geology, 20, 423-426. https://doi.org/10.1130/0091-7613(1992)020<0423:TNEAAB >2.3.CO;2

[48] Wheeler, W.H. and Karson, J.A. (1994) Extension and Subsidence Adjacent to a 
"Weak" Continental Transform: An Example from the Rukwa Rift, East Africa. Geology, 22, 625-628. https://doi.org/10.1130/0091-7613(1994)022<0625:EASATA >2.3.CO;2

[49] Waldron, J.W.F. (2005) Extensional Fault Arrays in Strike-Slip and Transtension. Journal of Structural Geology, 27, 23-34. https://doi.org/10.1016/j.jsg.2004.06.015

[50] Hill, D.P. (1977) A Model for Earthquake Swarms. Journal of Geophysical Research, 82, 1347-1357. https://doi.org/10.1029/JB082i008p01347

[51] Segall, P. and Pollard, D.D. (1980) Mechanics of Discontinuous Faults. Journal of Geophysical Research, 85, 4337-4350. https://doi.org/10.1029/JB085iB08p04337

[52] Sibson, R.H. (1985) Stopping of Earthquake Ruptures at Dilational Fault Jogs. Nature, 316, 248-251. https://doi.org/10.1038/316248a0

[53] De Paola, N., Holdsworth, R.E., Collettini, C., Mccaffrey, K.J.W. and Barchi, M.R. (2007) The Structural Evolution of Dilational Stepovers in Regional Transtensional Zones. In: Cunningham, W. D. \& Mann, P., Eds., Tectonics of Strike-Slip Restraining and Releasing Bends. Geological Society, 290, 433-445. https://doi.org/10.1144/SP190.17

[54] Chorowicz, J. and Sorlien, C. (1992) Oblique Extensional Tectonics in the Malawi Rift, Africa. Geological Society of America Bulletin, 104, 1015-1023. https://doi.org/10.1130/0016-7606(1992)104<1015:OETITM>2.3.CO;2

[55] Smit, J., Brun, J.P., Cloetingh, S. and Ben-Avraham, Z. (2008) Pull-Apart Basin Formation and Development in Narrow Transform Zones with Application to the Dead Sea Basin. Tectonics, 27, TC6018. https://doi.org/10.1029/2007TC002119

[56] Christie-Blick, N. and Biddle, K.T. (1985) Deformation and Basin Formation along Strike-Slip Faults. In: Biddle, K.T. and Christie-Blick, N., Eds., Strike-Slip Deformation, Basin Formation, and Sedimentation. Strike-Slip Deformation, Basin Formation, and Sedimentation, SEPM Special Publications, Tulsa, 1-34. https://doi.org/10.2110/pec.85.37.0001

[57] Sibson, R.H. (2001) Seismogenic Framework for Hydrothermal Transport and Ore Deposition. Reviews in Economic Geology, 14, 25-50. https://doi.org/10.5382/Rev.14.02

[58] Cox, S. F., Knackstedt, M. A. and Braun, J. (2001) Principles of Structural Control on Permeability and Fluid Flow in Hydrothermal Systems. In: Richards, J.P. and Tosdal, R.M., Eds., Structural Controls on Ore Genesis, Society of Economic Geologists, Littleton, 1-24. https://doi.org/10.5382/Rev.14.01

[59] Kim, Y.S., Peacock, D.C.P. and Sanderson, D.J. (2004). Fault Damage Zones. Journal of Structural Geology, 26, 503-517. https://doi.org/10.1016/j.jsg.2003.08.002

[60] King, G. and Nabelek, J. (1985) Role of Fault Bends in the Initiation and Termination of Earthquake Rupture. Science, 228, 984-987. https://doi.org/10.1126/science.228.4702.984

[61] Micklethwaite, S. and Cox, S.F. (2004) Fault-Segment Rupture, Aftershock-Zone Fluid Flow, and Mineralization. Geology, 32, 813-816. https://doi.org/10.1130/G20559.1

[62] Latham, J.P., Xiang, J., Belayneh, M., Nick, H.M., Tsang, C.F. and Blunt, M.J. (2013) Modelling Stress-Dependent Permeability in Fractured Rock Including Effects of Propagating and Bending Fractures. International Journal of Rock Mechanics \& Mining Sciences, 57, 100-112. https://doi.org/10.1016/j.ijrmms.2012.08.002

[63] Segall, P. and Pollard, D.D. (1983) Nucleation and Growth of Strike Slip Faults in Granite. Journal of Geophysical Research, 88, 555-568. https://doi.org/10.1029/JB088iB01p00555 
[64] Aydin, A. and Berryman, J.G. (2010) Analysis of the Growth of Strike-Slip Faults Using Effective Medium Theory. Journal of Structural Geology, 32, 1629-1642. https://doi.org/10.1016/j.jsg.2009.11.007

[65] Caine, J.S., Evans, J.P. and Forster, C.B. (1996) Fault Zone Architecture and Permeability Structure. Geology, 24, 1025-1028. https://doi.org/10.1130/0091-7613(1996)024<1025:FZAAPS >2.3.CO;2

[66] Wang, G., Mitchell, T.M., Meredith, P.G., Nara, Y. and Wu, Z. (2016) Influence of Gouge Thickness and Grain Size on Permeability of Macrofractured Basalt. Journal of Geophysical Research: Solid Earth, 121, 8472-8487. https://doi.org/10.1002/2016JB013363

[67] Wolfe, C.J., Bjarnason, I.T., VanDecar, J.C. and Solomon, S.C. (1997) Seismic Structure of the Iceland Mantle Plume. Nature, 385, 245-247. https://doi.org/10.1038/385245a0

[68] Bjarnason, I.T. (2008) An Iceland Hotspot Saga. Jökull, 58, 3-16.

[69] De Mets, C., Gordon, R.G., Argus, D.F. and Stein, S. (1994) Effect of Recent Revisions to the Geomagnetic Reversal Time Scale on Estimates of Current Plate Motions. Geophysical Research Letters, 21, 2191-2194. https://doi.org/10.1029/94GL02118

[70] Khodayar, M. and Björnsson, S. (2018) Structures and Styles of Deformation in Rift, Ridge, Transform Zone, Oblique Rift and a Microplate Offshore/Onshore North Iceland. International Journal of Geosciences, 9, 461-511. https://doi.org/10.4236/ijg.2018.98029

[71] Hreinsdóttir, S., Einarsson, P. and Sigmundsson, F. (2001) Crustal Deformation at the Oblique Spreading Reykjanes Peninsula, SW Iceland: GPS Measurements from 1993 to 1998. Journal of Geophysical Research, 106, 13803-13816. https://doi.org/10.1029/2001JB000428

[72] Talwani, M., Windisch, C.C. and Langseth, M.G. (1971) Reykjanes Ridge Crest: A Detailed Geophysical Study. Journal of Geophysical Research, 76, 473-516. https://doi.org/10.1029/JB076i002p00473

[73] Parson, L.M., Murton, B.J., Searle, R.C., Booth, D., Evans, J., Field, P., Keeton, J., Laughton, A., McAllister, E., Millard, N., Redbourne, L., Rouse, I., Shor, A., Smith, D., Spencer, S., Summerhayes, C. and Walker, C. (1993) En Échelon Axial Volcanic Ridges at Reykjanes Ridge: A Life Cycle of Volcanism and Tectonics. Earth and Planetary Science Letters, 117, 73-87. https://doi.org/10.1016/0012-821X(93)90118-S

[74] Brandsdóttir, B., Riedel, C., Richter, B., Helgadóttir, G., Kjartansson, E., Detrick, R., Dahm, T., Mayer, L., Calder, B. and Driscoll, N. (2005) Multibeam Bathymetric Maps of the Kolbeinsey Ridge and Tjörnes Fracture Zone, N-Iceland. Abstract, European Geophysical Union General Assembly, Nice, France.

[75] McDougall, I., Saemundsson, K., Jóhannesson, H., Watkins, N.D. and Kristjánsson, L. (1977) Extension of the Geomagnetic Time Scale to 6.5 m.y.: K-Ar Dating, Geological and Paleomagnetic Study of a 3,500-m Lava Succession in Western Iceland. Bulletin of Geological Society of America, 88, 1-15. https://doi.org/10.1130/0016-7606(1977)88<1:EOTGPT>2.0.CO;2

[76] Jóhannesson, H. (1980) Evolution of the Rift Zones in Western Iceland (in Icelandic with English Summary). Náttúrufræedingurinn, 50, 13-31.

[77] Kristjánsson, L. (2008) Paleomagnetic Research on Icelandic Lava Flows. Jökull, 58, 101-116.

[78] Harðarson, B.S., Fitton, J.G., Ellam, R.M. and Pringle, M.S. (1997). Rift Reloca- 
tion-A Geochemical and Geochronological Investigation of a Paleo-Rift in Northwest Iceland. Earth and Planetary Science Letters, 153, 181-196. https://doi.org/10.1016/S0012-821X(97)00145-3

[79] Sigurðsson, H. (1967) Dykes, Fractures and Folds in the Basalt Plateau of Western Iceland. In: Björnsson, S., Ed., Iceland and Mid-Ocean Ridges, Societas Scientiarum Islandica, Prentsmidjan Leiftur, Reykjavik, 162-169.

[80] Jancin, M., Young, K.D., Voight, B., Aronson, J.L. and Saemundsson, K. (1985) Stratigraphy and K/Ar Ages across the West Flank of the Northeast Iceland Axial Rift Zone, in Relation to the $7 \mathrm{Ma}$ Volcano-Tectonic Reorganization of Iceland. Journal of Geophysical Research, 90, 9961-9985.

https://doi.org/10.1029/JB090iB12p09961

[81] Khodayar, M. and Einarsson, P. (2002) Strike-Slip Faulting, Normal Faulting, and Lateral Dike Injections along a Single Fault: Field Example of the Gljúfurá Fault Near a Tertiary Oblique Rift-Transform Zone, Borgarfjörður, West Iceland. Journal of Geophysical Research: Solid Earth, 107, ETG 5-1-ETG 5-16. https://doi.org/10.1029/2001JB000150

[82] Sykes, L.R. (1967) Mechanism of Earthquakes and Nature of Faulting on the Mid-Oceanic Ridges. Journal of Geophysical Research, 72, 2131-2153.

https://doi.org/10.1029/JZ072i008p02131

[83] Ward, P.L. (1971) New Interpretation of the Geology of Iceland. Geological Society of America Bulletin, 82, 2991-3012. https://doi.org/10.1130/0016-7606(1971)82[2991:NIOTGO]2.0.CO;2

[84] Jakobsdóttir, S.S. (2008) Seismicity in Iceland: 1994-2007. Jökull, 58, 75-100.

[85] Stefánsson, R., Guðmundsson, G.B. and Halldórsson, P. (2008) Tjörnes Fracture Zone. New and Old Seismic Evidences for the Link between the North Iceland Rift Zone and the Mid-Atlantic Ridge. Tectonophysics, 447, 117-126. https://doi.org/10.1016/j.tecto.2006.09.019

[86] Schäfer, K. (1972) Transform Faults in Iceland. Geologische Rundschau, 61, 942-960. https://doi.org/10.1007/BF01820899

[87] Mamula, N. and Voight, B. (1985) Tectonic Analysis of Lineaments Near a Spreading Axis, Northeastern Iceland. Tectonophysics, 116, 63-93. https://doi.org/10.1016/0040-1951(85)90222-7

[88] Khodayar, M., Björnsson, S., Víkingsson, S. and Jónsdóttir, G.S. (2020) Unstable Rifts, a Leaky Transform Zone and a Microplate: Analogues from South Iceland. Open Journal of Geology, 10, 317-367. https://doi.org/10.4236/ojg.2020.104017

[89] Khodayar, M. (1999) On the Pattern of Faults and Dykes in Borgarfjörður, W-Iceland, Jökull, 47, 21-44.

[90] Khodayar, M. and Franzson, H. (2007) Fracture Pattern of Pjórsárdalur Central Volcano with Respect to Rift-Jump and a Migrating Transform Zone in South Iceland. Journal of Structural Geology, 29, 898-912.

https://doi.org/10.1016/j.jsg.2006.11.007

[91] Ziegler, M., Rajabi, M., Heidbach, O., Hersir, G.P., Ágústsson, K., Árnadóttir, S. and Zanga, A. (2016) The Stress Pattern of Iceland. Tectonophysics, 674, 101-113. https://doi.org/10.1016/j.tecto.2016.02.008

[92] Kristjánsson, L. and Jónsson, G. (1998) Aeromagnetic Results and the Presence of an Extinct Rift Zone in Western Iceland. Journal of Geodynamics, 25, 99-108. https://doi.org/10.1016/S0264-3707(97)00009-4

[93] Walker, G.P.L. (1960) Zeolite Zones and Dike Distribution in Relation to the Struc- 
ture of the Basalts of Eastern Iceland. Journal of Geology, 68, 515-528. https://doi.org/10.1086/626685

[94] Hjartarson, Á. (2003) The Skagafjörður Unconformity, North Iceland, and Its Geological History. Geological Museum. Ph.D. Thesis, University of Copenhagen, Copenhagen, $248 \mathrm{p}$.

[95] Sæmundsson, K., Sigurgeirsson, M.Á., Hjartarson, Á., Kaldal, I., Kristinsson, S.G. and Víkingsson, S. (2016) Geological Map of Southwest Iceland, 1:100,000. 2nd Edition, Iceland GeoSurvey (ÍSOR), Reykjavík.

[96] Franzson, H. (2004) The Reykjanes High-Temperature Geothermal System. Geological and Geothermal Model. Iceland GeoSurvey, Report, ÍSOR-2004/012, 60 p.

[97] Geirsson, H., LaFemina, P., Árnadóttir, Th., Sturkell, E., Sigmundsson, F., Travis, M., Schmidt, P., Lund, B., Hreinsdóttir, S. and Bennett, R. (2012) Volcano Deformation at Active Plate Boundaries: Deep Magma Accumulation at Hekla Volcano and Plate Boundary Deformation in South Iceland. Journal of Geophysical Research, 117, B11409. https://doi.org/10.1029/2012JB009400

[98] Decriem, J., Árnadóttir, T., Hooper, A., Geirsson, H., Sigmundsson, F., Keiding, M., Ófeigsson, B.G., Hreinsdóttir, S., Einarsson, P., La Femina, P. and Bennett, R.A. (2010) The 2008 May 29 Earthquake Doublet in SW Iceland. Geophysical Journal International, 181, 1128-1146. https://doi.org/10.1111/j.1365-246X.2010.04565.X

[99] Clifton, A.E. and Kattenhorn, S.A. (2006) Structural Architecture of a Highly Oblique Divergent Plate Boundary Segment. Tectonophysics, 419, 27-40. https://doi.org/10.1016/j.tecto.2006.03.016

[100] Keiding, M., Árnadóttir, Th., Jónsson, S., Decriem, J. and Hooper, A. (2010) Plate Boundary Deformation and Man-Made Subsidence around Geothermal Fields on the Reykjanes Peninsula, Southwest Iceland. Journal of Volcanology and Geothermal Research, 194, 139-149. https://doi.org/10.1016/j.jvolgeores.2010.04.011

[101] Klein F.W., Einarsson, P. and Wyss, M. (1977) The Reykjanes Peninsula, Iceland, Earthquake Swarm of September 1972 and Its Tectonic Significance. Journal of Geophysical Research, 82, 856-888. https://doi.org/10.1029/JB082i005p00865

[102] Björnsson, S., Einarsson, P., Tulinius, H. and Hjartardóttir, Á.R. (2020) Seismicity of the Reykjanes Peninsula 1971-1976. Journal of Volcanology and Geothermal Research, 391, Article ID: 106369. https://doi.org/10.1016/j.jvolgeores.2018.04.026

[103] Guðnason, E.Á. and Ágústsson, K. (2014) Earthquake Swarm on Reykjanes in October 2013. Iceland GeoSurvey Report, ÍSOR-2014/017, 25 p.

[104] Guðnason, E.Á., Ágústsson, K., Gunnarsson, K. and Flóvenz, Ó.G. (2015) Seismic activity on Reykjanes December 2014-December 2015. Iceland GeoSurvey Report, ÍSOR-2015/068, $31 \mathrm{p}$.

[105] Khodayar, M. and Björnsson, S. (2014) Fault Ruptures and Geothermal Effects of the Second Earthquake, 29 May 2008, South Iceland Seismic Zone. Geothermics, 50, 44-65. https://doi.org/10.1016/j.geothermics.2013.07.002

[106] Parameswaran, R.M., Thorbjarnardóttir, B.S., Stefánsson, R. and Bjarnason, I.T. (2020) Seismicity on Conjugate Faults in Ölfus, South Iceland: Case Study of the 1998 Hjalli-Ölfus Earthquake. Journal of Geophysical Research: Solid Earth, 125, e2019JB019203. https://doi.org/10.1029/2019JB019203

[107] Khodayar, M., Björnsson, S., Guðnason, E.Á., Níelsson, S., Axelsson, G. and Hickson, C. (2018) Tectonic Control of the Reykjanes Geothermal Field in the Oblique Rift of SW Iceland: From Regional to Reservoir Scales. Open Journal of Geology, 8, 333-382. https://doi.org/10.4236/ojg.2018.83021

[108] Karlsdóttir, R., Vilhjálmsson, A.M. and Guðnason, E.Á. (2020) Three-dimensional 
inversion of magnetotelluric (MT) resistivity data from Reykjanes high temperature field in SW Iceland. Journal of Volcanology and Geothermal Research, 391, Article ID: 106498. https://doi.org/10.1016/j.jvolgeores.2018.11.019

[109] Einarsson, P., Klein, F.W. and Björnsson, S. (1977) The Borgarfjörður Earthquakes of 1974 in West Iceland. Bulletin of the Seismological Society of America, 67, 197-208.

[110] Flóvenz, Ó. and Steingrímsson, B. (2009) Geothermal Resources of Iceland. Geothermal Research Council Transactions, 33, 383-387.

[111] Arnórsson, S., Axelsson, G. and Sæmundsson, K. (2008) Geothermal Systems in Iceland. Jökull, 58, 269-302.

[112] Jakobsdóttir, S.S. and Guðmundsson, G.B. (2012) Seismic Activity in Hellisheiði and Nesjavellir. Spring Meeting of Geological Society of Iceland, Reykjavik, April 2012, p. 66.

[113] Brandsdóttir, B., Parsons, M., White, R.S., Guðmundsson, Ó., Drew, J. and Porbjarnardóttir, B.S. (2010) The May 29th 2008 Earthquake Aftershock Sequence within the South Icelandic Seismic Zone: Fault Locations and Source Parameters of Aftershocks. Jökull, 60, 23-46.

[114] Friðleifsson, G.Ó., Elder, W.A., Zierenberg, R.A., Fowler, A., Weisenberger, T., Mesfin, K., Sigurðsson, Ó., Níelsson, S., Einarsson, G., Óskarsson, F., Guðnason, E.Á., Tulinius, H., Hokstad, K., Benoit, G., Nono, F., Loggia, D., Parat, F., Cichy, S.B., Escobedo, D. and Mainprice, D. (2020) The Iceland Deep Drilling Project at Reykjanes: Drilling into the Root Zone of a Black Smoker Analog. Journal of Volcanology and Geothermal Research, 391, Article ID: 106435. https://doi.org/10.1016/j.jvolgeores.2018.08.013

[115] Hensch, M., Lund, B., Árnadóttir, T. and Brandsdóttir, B. (2016) Temporal Stress Changes Associated with the 2008 May 29 Mw 6 Earthquake Doublet in the Western South Iceland Seismic Zone. Geophysical Journal International, 204, 544-554. https://doi.org/10.1093/gji/ggv465

[116] Bergerat, F., Angelier, J. and Villemin, T. (1990) Fault Systems and Stress Patterns on Emerged Oceanic Ridges: A Case Study in Iceland. Tectonophysics, 179, 183-197. https://doi.org/10.1016/0040-1951(90)90290-O

[117] Khodayar, M., Björnsson, S., Níelsson, S., Axelsson, G. and Franzson, F. (2014) Preliminary Structural Analysis of Reykjanes for Re-injection. Report Iceland GeoSurvey, ÍSOR-2014/039, 96 p.

[118] Khodayar, M., Axelsson, G. and Steingrímsson, B. (2015) Potential Structural Flow Paths for Tracers and Source Faults of Earthquakes at Húsmúli, Hengill, South Iceland. Report Iceland GeoSurvey, ÍSOR-2015/035, 42 p.

[119] Jóhannesson, H. and Sæmundsson, K. (1998) Geological Map of Iceland-Tectonics, 1:500,000. Icelandic Institute of Natural History, Reykjavík.

[120] La Femina, P.C., Dixon, T.H., Malservisi, R., Árnadóttir, T., Sturkell, E., Sigmundsson, F. and Einarsson, P. (2005) Geodetic GPS Measurements in South Iceland: Strain Accumulation and Partitioning in a Propagating Ridge System. Journal of Geophysical Research: Solid Earth, 110, B11405. https://doi.org/10.1029/2005JB003675

[121] Sæmundsson, K. (1995) Geological Map of Hengill, 1:50.000. Orkustofnun, Reykjavík. 